\title{
The role of sea-salt emissions and heterogeneous chemistry in the air quality of polluted coastal areas
}

\author{
E. Athanasopoulou ${ }^{1}$, M. Tombrou ${ }^{1}$, S. N. Pandis ${ }^{2}$, and A. G. Russell ${ }^{3}$ \\ ${ }^{1}$ National and Kapodistrian University of Athens, Faculty of Physics, Dept. of Environmental Physics \\ and Meteorology, Athens, Greece \\ ${ }^{2}$ Dept. of Chemical Engineering, University of Patras, 26500 Patras, Greece \\ ${ }^{3}$ School of Civil and Environmental Engineering, Georgia Inst. of Technology, 311 Ferst Drive NW, \\ Atlanta, GA 30332-0512, USA
}

Received: 3 January 2008 - Published in Atmos. Chem. Phys. Discuss.: 25 February 2008

Revised: 12 June 2008 - Accepted: 12 August 2008 - Published: 1 October 2008

\begin{abstract}
Open-ocean and surf-zone sea-salt aerosol (SSA) emission parameterizations are incorporated in the CAMx aerosol model and applied over an area with an extended Archipelago (Greece), with a fine grid nested over the highly populated Attica peninsula. The maximum indirect impact of SSA on $\mathrm{PM}_{10}$ mass (35\%) is located over a marine area with moderate SSA production and elevated shipping emissions (central Aegean Sea) where SSA interacts with anthropogenic nitric acid forming sodium nitrate. SSA increases $\mathrm{PM}_{10}$ levels in the Athens city center up to $25 \%$ during stable onshore winds. Under such conditions both open-ocean and surf-zone mechanisms contribute to aerosol production over Attica. A hybrid scheme for gas-to-particle mass transfer is necessary for accurately simulating semi-volatile aerosol components when coarse SSA is included. Dynamically simulating mass transfer to the coarse particles leads to a quadrupling of predicted $\mathrm{PM}_{10}$ nitrate in the Athens city center and up to two orders of magnitude in its coarse mass in comparison to using a bulk equilibrium approach.
\end{abstract}

\section{Introduction}

Sea salt is one of the major atmospheric aerosol components on a global scale (Lewis and Schwartz, 2004) and can significantly impact particulate matter concentrations. Sea-salt aerosol (SSA) is mainly produced by bursting bubbles during whitecap formation in the open-ocean (Monahan et al., 1986). A more localized mechanism of SSA production involves waves breaking in the surf zone. This mechanism may

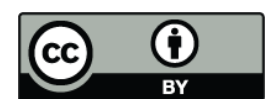

Correspondence to: E. Athanasopoulou (eathana@phys.uoa.gr) affect areas even at a distance of $25 \mathrm{~km}$ from the coastline and can dominate the coastal SSA levels (Monahan, 1995; De Leeuw et al., 2000; Woodcock et al., 1963).

The diameter of SSA ranges from less than $0.2 \mu \mathrm{m}$ to greater than $2000 \mu \mathrm{m}$. The ambient SSA mass distribution is dominated by particles in the $1-10 \mu \mathrm{m}$ diameter range. In a typical urban atmosphere, measured mass size distributions of sodium and chloride concentrations show a dominant peak around $4 \mu \mathrm{m}$ (Wall et al., 1988). Particles smaller than $1 \mu \mathrm{m}$ can make substantial contributions to cloud condensation nuclei concentrations (Pierce and Adams, 2006), while particles larger than $50 \mu \mathrm{m}$ have a very short atmospheric lifetime and play a negligible role in atmospheric chemistry (Lewis and Schwartz, 2004).

SSA participates in atmospheric chemistry by interacting with atmospheric pollutants. For example, sodium chloride in polluted areas (e.g. cities or areas with ship-routes) reacts with sulfuric and nitric acid producing sodium sulfate and nitrate together with hydrochloric acid gas. The timescale of these reactions with coarse SSA can be several hours (Meng and Seinfeld, 1996) and leads to a chloride "deficit" in the SSA (Seinfeld and Pandis, 1998). As sea-salt particles are transported inland during periods with onshore winds, they compete with the fine aerosol particles for sulfuric and nitric acid changing both the concentration and size distribution of the corresponding sulfate, nitrate and chloride salts.

The first atmospheric aerosol thermodynamics modules (EQUIL, KEQUIL, MARS, MARS-A) neglected the role of sea-salt, and focused on the sulfate-nitrate-ammoniumwater system (Bassett and Seinfeld, 1983; 1984; Saxena et al., 1986; (Binkowski and Shankar, 1995). This can lead to errors in the simulated chemical composition of aerosol and the related gas-phase species, especially for coastal and

Published by Copernicus Publications on behalf of the European Geosciences Union. 
marine-affected areas (Bessagnet et al., 2004; Hodzic et al., 2006). The second generation of such modules (e.g. SEQUILIB, SCAPE, EQUISOLV, ISORROPIA and ISORROPIA II) describes the interactions among sodium and chloride and the rest of the major inorganic aerosol species (Nenes et al., 1998; Zhang et al., 2000; Fountoukis and Nenes, 2007). Nevertheless, even models incorporating such modules can underestimate $\mathrm{PM}_{10}$ aerosol mass in coastal areas when they do not include SSA emissions (Mebust et al., 2003). Errors can also occur when models assume instantaneous mass transfer between the gas and condensed phases in areas with high sea-salt concentrations (Lurmann et al., 1997). Capaldo et al. (2000) argued that in these cases the total nitrate concentration is underestimated and the nitrate distribution is biased towards the fine aerosol.

Several authors have proposed parameterizations for seasalt emissions fluxes (Ling et al., 1980; Gathman, 1982; Blanchard, 1963; Fairall et al., 1983; Monahan et al., 1986; Bortkovskii, 1987; Woolf et al., 1988; Andreas, 1992; Iida et al., 1992; Wu, 1992; 1993; Smith et al., 1993; O'Dowd et al., 1997; Andreas, 1998; Smith and Harrison, 1998; De Leeuw et al., 2000; Hoppel et al., 2002; Martensson et al., 2003; Gong, 2003; Clarke et al., 2006). These expressions typically calculate the number flux density of SSA as a function of the wind speed at $10 \mathrm{~m}$ a.s.l. $\left(\mathrm{U}_{10}\right)$ and at a specific ambient relative humidity (usually at $80 \% \mathrm{RH}$ ). Martensson et al. (2003) is an exception and includes a temperature dependence and O'Dowd et al. (1997) specify the concentration rather than the emission flux. Parameterization applicability depends on SSA size range and wind speed. Almost all source functions predict open-ocean produced aerosol, except DEL00 (De Leeuw et al., 2000), which is a surf-zone parameterization. CL06 (Clarke et al., 2006) is the parameterization extending to the smallest particle size $(0.01 \mu \mathrm{m}$ dry particle diameter); G-M03 (Gong, 2003) is based on the classical formulation of Monahan et al. (1986) and has been found to agree reasonably well with observations up to $40 \mu \mathrm{m}$ in diameter (at $80 \% \mathrm{RH}$ ).

A number of attempts have been made to incorporate SSA source functions in atmospheric models. Most applications are on a global scale (Alexander et al., 2005; Gong et al., 1997; Witek et al., 2007; Pierce and Adams, 2006; Gong, 2003; Ma et al., 2008), while fewer studies refer to regional, though low resolution applications (Spyridaki et al., 2006; Foltescu et al., 2004; Pryor et al., 2008; Nolte et al., 2008).

$\mathrm{Ma}$ et al. (2008) show that radiative forcing for sea salt is similar to that for sulfate aerosol, while Pierce and Adams (2006) showed an increase in predicted CCN concentrations when sea-salt emissions are included, though these values are quite sensitive to the mean wind speeds and distributions. Witek et al. (2007) reported good correlation between SSA simulation results and data from shipboard experiments, although their predictions were higher. This overprediction increased at high wind speeds. Higher sodium predictions at marine-affected ground stations in Northern
Europe were also reported by Foltescu et al. (2004), who stressed the model's difficulty in capturing deposition in complex terrain, the coarse particle sampling difficulties, as well as mass differences caused by area-to-point comparisons. On the other hand, Spyridaki et al. (2006) found under-predictions of marine aerosol species over the southeastern part of Greece, probably due to underestimation of sea-salt boundary concentrations. Pryor et al. (2008) showed that sea-spray is not an inert addition to the aerosol, as it affects particle composition and predominantly nitrate concentrations. This is also stressed by Shankar et al. (2005) although the effect was underestimated by their model due to the underestimation of the fine SSA and to the exclusion of surf-zone emissions from the applied parameterization. The latter is further stressed by the study of Vignati et al. (2001), which concludes that surf-zone aerosol provides additional surface for heterogeneous reactions and greatly impacts marine-affected areas. Another issue is that grid cells of the regional models cause an artificial smoothing of the coastline and of the surf-zone width, leading to inaccuracies in the calculation of surf-zone emissions.

This paper describes the incorporation of a comprehensive SSA algorithm in the CAMx aerosol model (Environ, 2004). The main goal is to examine the interactions between anthropogenic pollution and marine aerosol over a populated area with an extended Archipelago. The selected area for model application is Greece, situated in the southeastern Mediterranean. The grid system used combines a highresolution nested domain over Attica peninsula with a parent domain over Greece and surrounding areas and the applied SSA emission algorithms describe both open-ocean and surfzone particle production. The system is then used to investigate SSA contributions to aerosol mass together with chemical interactions between sea salt and atmospheric pollutants. Additionally, the effectiveness of the open-ocean versus surfzone production mechanisms is investigated. Finally, it is examined whether is crucial to dynamically model the gas-toparticle conversion of condensable material when it contains semi-volatile ions (chloride, nitrate).

\section{Air quality model}

CAMx is a 3-D, Eulerian chemical transport model. The version of the model used in this study (4.11s) uses the CB-IV gas-phase chemical mechanism (Gery et al., 1989), the RADM algorithm for cloud chemistry (Chang et al., 1987), the SOAP scheme for the organic species partitioning (Strader et al., 1998) and ISORROPIA for the thermodynamic equilibrium of inorganic aerosol (Nenes et al., 1998). The system treated by ISORROPIA includes sodium $\left(\mathrm{Na}^{+}\right)$, ammonium $\left(\mathrm{NH}_{4}^{+}\right)$, chloride $\left(\mathrm{Cl}^{-}\right)$, sulfate $\left(\mathrm{SO}_{4}^{=}\right)$, nitrate $\left(\mathrm{NO}_{3}^{-}\right)$and water $\left(\mathrm{H}_{2} \mathrm{O}\right)$, which are partitioned between gas, liquid and solid phases. Sulfate and sodium completely reside in the aerosol phase, while other aerosol species are 
found in both phases, based largely on the value of sulfate and sodium molar ratio $\left(\mathrm{Na}^{+}+\mathrm{NH}_{4}^{+} / \mathrm{SO}_{4}^{=}\right.$and $\mathrm{Na}^{+} / \mathrm{SO}_{4}^{=}$, respectively).

Mass transfer between gas and condensed phases is calculated using the hybrid approach (Capaldo et al., 2000), which assumes instantaneous equilibrium between gases and fine aerosols (equilibrium approach) and solves the mass transfer rate equations for the coarse mass (dynamic approach). Fine particles achieve equilibrium with the gas phase within a few minutes while tens of minutes or even hours are necessary for the equilibration of coarse particles. The threshold diameter between the two approaches was set at $2.5 \mu \mathrm{m}$ in this study, in order to achieve both speed and accuracy during simulations.

CAMx employs a sectional approach for the aerosol mass distribution between 0.04 and $40 \mu \mathrm{m}$ (particle diameter). Ten discrete and internally mixed size sections (bins), each consisting of thirteen chemical aerosol components (primary: organic and elemental carbon, chloride, sodium, sulfate ions and crustal material; secondary: four organics, water, ammonium, nitrate and sulfate ions) lead to 130 aerosol "species" treated by the model.

\section{Method}

\subsection{Modeling domain}

The CAMx simulation area covers the greater Greece area (parent domain) using a spatial resolution of $6 \mathrm{~km}$, while a finer resolution of $2 \mathrm{~km}$ is used in the nested domain centered on the Attica peninsula (Fig. 1). The areas of the parent and the nested domain are $777924 \mathrm{~km}^{2}(147 \times 147$ cells $)$ and $21600 \mathrm{~km}^{2}(75 \times 72$ cells), respectively. In the vertical, the physical layer height structure consists of 14 levels up to $5.1 \mathrm{~km}$, with the top of the first layer approximately at $72 \mathrm{~m}$.

Greece has an extended coastline and a large number of islands, making it an ideal case for the study of sea salt effects produced from open-ocean and surf-zone production mechanisms. Greece can be divided into four types of environments with respect to SSA and anthropogenic emissions: 1) low emission offshore areas with elevated SSA emissions, 2) offshore areas with SSA and sea-transport (shipping) emissions, 3 ) inland areas near the coastline, with emissions due to urban and industrial activities and 4) non-coastal inland areas less affected by SSA. The most representative area for the third case is in the Attica peninsula, where Athens is situated and is surrounded by an airport, three harbors and many industrial sources.

\subsection{Meteorology and episode selection}

The criteria for the selection of the simulation period included: (a) representative wind speed values over the area of interest, as wind speed controls SSA emissions, (b) wind direction favorable for the transfer of sea-salt towards the
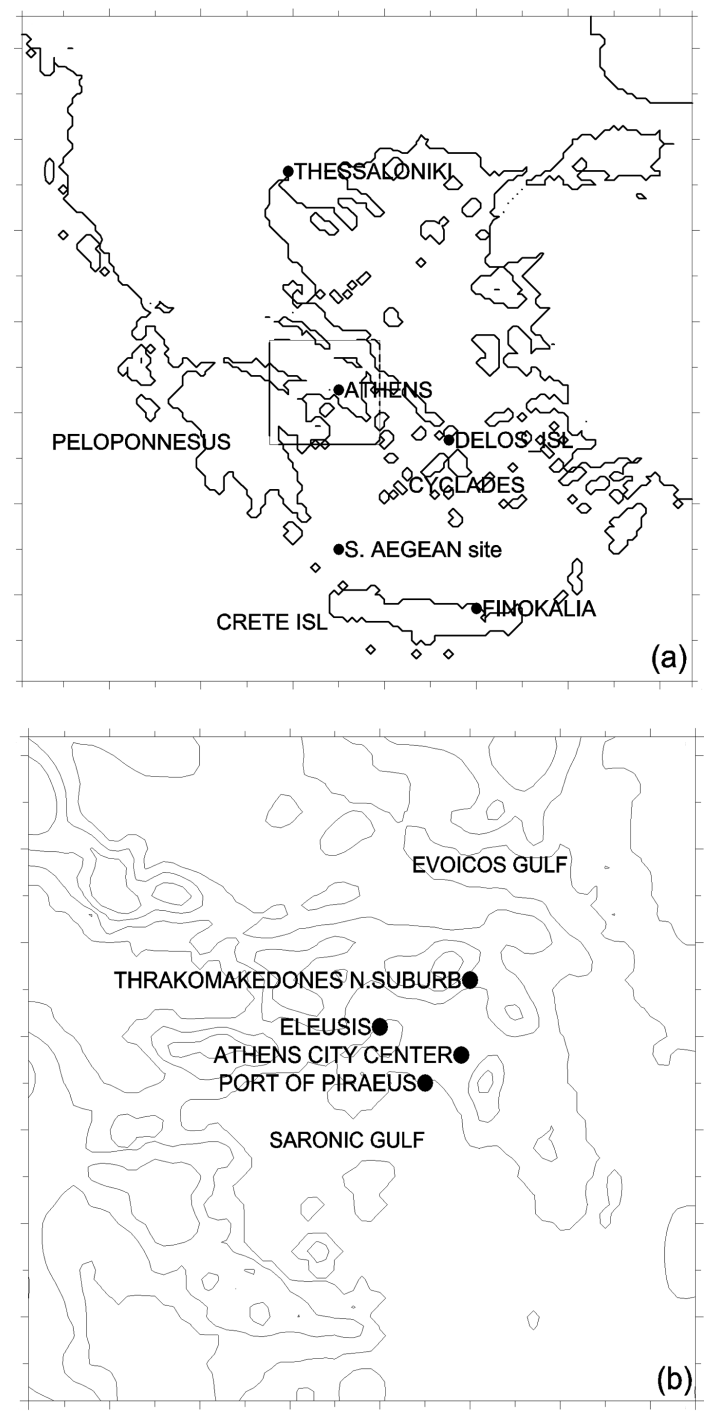

Fig. 1. Application domain and monitoring sites: (a) the parent domain (covers Greece, with outside ticks at $60 \mathrm{~km}$ intervals and (b) the nested domain (embedded rectangle) covers the Attica peninsula, with outside ticks at $10 \mathrm{~km}$. Topography contours at $300 \mathrm{~m}$ intervals.

Athens basin, (c) elevated pollution over Athens and (d) available anthropogenic and biogenic emission inventories. Open anti-cyclonic (OA) synoptic conditions frequently occur over Greece $\left(38 \% \mathrm{yr}^{-1}\right)$, are usually clear and sunny and are characterized by relatively weak synoptic winds that favor development of sea-breeze circulation over the Athens basin during summer (Kassomenos et al., 1998; Melas et al., 1998; Ziomas et al., 1995). Thus, we focused on summer OA events. Unfortunately, for the candidate periods that satisfied the above four criteria there were no available measurement data sets (e.g., aerosol composition) for the evaluation of the model. The period of 21-24 June 1998 was selected, with 24 June being the focus of the modeling (the first three days were used for model initialization). 


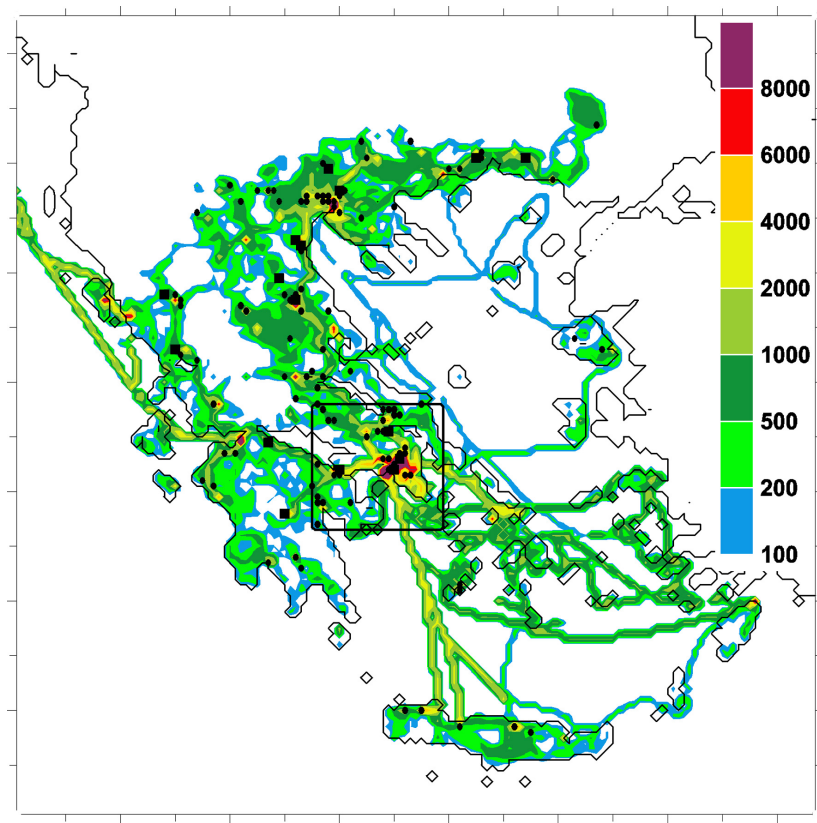

Fig. 2. Spatial distribution of the daily average $\mathrm{NO}_{\mathrm{x}}$ emission rates $\left(\mathrm{kg} \mathrm{km}^{-1} \mathrm{hr}^{-1}\right)$ over Greece, during summer. Solid rectangles show point source emissions greater than $500 \mathrm{~kg} \mathrm{hr}^{-1}$ and circles are the rest industrial sources.

Meteorological fields used in CAMx are produced by the fifth generation Penn State/NCAR Mesoscale Model, MM5 (Anthes and Warner, 1978). The applied MM5 version includes recent advances in the description of the urban boundary layer, such as incorporation of the anthropogenic heat and heat storage fluxes, as well as modifications in surface stress and fluxes of heat and momentum (Dandou et al., 2005). MM5 meteorological output is used to generate the CAMx input fields through the pre-processor "mm5camxv4.2" (http://www.camx.com/down/support.php). The vertical diffusivity $\left(K_{v}\right)$ profiles can be calculated by different methods. Sensitivity runs for the current application revealed that the O'Brien (1970) parameterization produced more realistic first layer $K_{v}$ values compared to that of Byun et al. (1999).

During the day examined in detail (24 June 1998) WestNorth West (WNW) wind speed maxima (about $11 \mathrm{~m} \mathrm{~s}^{-1}$ ) are predicted around the island of Crete, while lower wind speed values (up to $4 \mathrm{~m} \mathrm{~s}^{-1}$ ) are predicted north of Crete (Cyclades islands area). Winds from the south sector are constant over the central and northern Aegean Sea. The Attica peninsula is affected by the WNW flow (about $7 \mathrm{~m} \mathrm{~s}^{-1}$ ) during the early morning and late night hours and by a SSW flow during the rest of the day. SSW flow is intensified by the air-mass entrainment from the Cyclades area (southern boundary) and is fully developed during the afternoon (about $6 \mathrm{~m} \mathrm{~s}^{-1}$ ).

\subsection{Initial and boundary conditions}

Initial and boundary conditions for the day examined are assumed to be spatially and temporally invariant for the parent domain. The concentrations for the main gaseous pollutants are typical values for the area during the warm period, i.e. $50 \mathrm{ppb}$ for $\mathrm{CO}, 1 \mathrm{ppb}$ for $\mathrm{NO}_{\mathrm{x}}, 3 \mathrm{ppb}$ for $\mathrm{SO}_{2}$ and $40 \mathrm{ppb}$ for $\mathrm{O}_{3}$. For the rest of the gaseous species, lower bound concentrations are automatically set by the model $\left(10^{-6} \mathrm{ppb}\right)$. The simulated synoptic condition (OA) does not have southern winds that favor African dust transport in the Mediterranean atmosphere, and this was confirmed by satellite imagery for the specific period (http: //toms.gsfc.nasa.gov/aerosols/aerosols_v8.html), thus the default aerosol boundary concentrations are used for this study $\left(10^{-9} \mu \mathrm{g} \mathrm{m}^{-3}\right)$. Tests showed that sea salt boundary conditions have a significant aerosol impact to only about $20 \mathrm{~km}$ into the domain, thus default values are again acceptable.

In order to avoid the transient effects associated with initial conditions, we use a 3-day "spin-up" modeling period. Sensitivity tests have indicated that this 3-day start-up period is sufficient to minimize the role of initial conditions on aerosol concentrations for the parent domain.

\section{Emissions - implementation of SSA in the model}

Hourly emissions of $\mathrm{NO}_{\mathrm{x}}, \mathrm{SO}_{2}, \mathrm{NMVOC}, \mathrm{CO}, \mathrm{NH}_{3}$, isoprene, terpenes and bulk $\mathrm{PM}_{10}$ from Greek industries, road transport, central heating, maritime activities, railways, air traffic, agricultural activities and forests were provided by the Greek Ministry of the Environment for a typical summer and a winter weekday and weekend of 2002. The typical summer weekday emission rates (without fire emissions) are used in the current study. There were no major biomass burning events during the simulated period. The NMVOC emission speciation profiles used here are described by Bossioli et al. (2002). The spatial distribution of anthropogenic emissions shows the importance of both on-shore and shipping emissions (Fig. 2). Seasonal $\mathrm{NH}_{3}$ emissions from agricultural activities were provided by Sotiropoulou et al. (2003) for the Attica area. This information was then combined with the land type database to estimate $\mathrm{NH}_{3}$ emission rates from forest, agricultural and range land types which were then applied to the rest area of Greece. Hourly $\mathrm{NH}_{3}$ emission rates follow the daily temperature variation over Attica.

$\mathrm{PM}_{10}$ dust emission factors for road abrasion and tire/brake wear per vehicle were based on IIASA (http: //www.iiasa.ac.at/ rains/PM/). This information was then combinened with the spatial-temporal distribution of vehicles and the $\mathrm{NO}_{\mathrm{x}}$ traffic emissions distribution. Bulk $\mathrm{PM}_{10}$ mass rates, by source, were split into 5 chemical species and distributed by size, according to literature review (CARB database: http://www. arb.ca.gov/ei/speciate/dnldopt.htm; SPECIATE (version 3.2) 


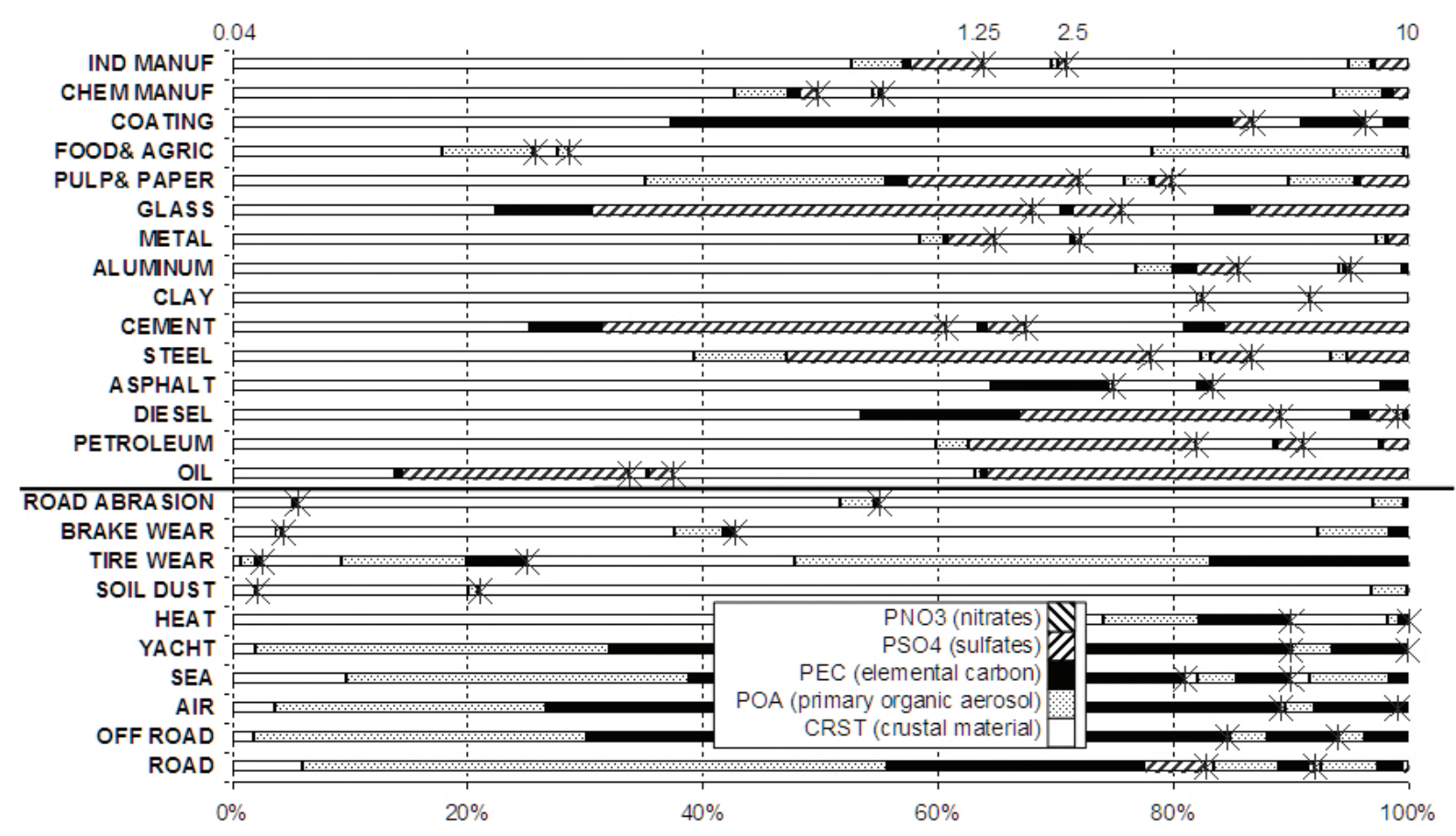

Fig. 3. Speciation profiles of $\mathrm{PM}_{10}$ emissions from the main area (lower section) and point (upper section) sources. Crosses define the main size sections of $\mathrm{PM}_{10}$ speciation. Their cut-off diameters $(\mu \mathrm{m})$ are shown on top.

software: http://www.epa.gov/ttn/chief/software/speciate/ speciate32.html; TNO/CEPMEIP database: http://www. air.sk/tno/cepmeip/em_factors.php; EMPA, 2000) (Fig. 3). Transportation sources emit mostly fine aerosol mass $\left(\mathrm{PM}_{2.5}\right)$ comprised mainly of elemental carbon and organic PM, while re-suspended mass (from soil or roads) is mostly coarse inorganic and entails with a small amount of secondary nitrates. Point aerosol emissions distribute more evenly to the size bins and are mainly inorganic (sulfates and crustal material).

\subsection{Implementation of SSA in the model}

The SSA emission algorithm implemented in this study combines the CL06 source function for smaller particles (reaches submicron particles but is applicable for sizes not exceeding $8 \mu \mathrm{m}$ in diameter) and G-M03 for the larger particles (Table 1). Both equations are applied in the open-ocean cells of both domains. DELO0 is used for the parameterization of the surf-produced SSA and is applied at the coastal cells (land cells adjacent to cells covered totally by sea). The original source functions were adjusted to ambient RH (45-99\%, as predicted by MM5) and salinity $(S=38.5)$ for the Mediterranean Sea conditions (Lewis and Schwartz, 2004) by using the correction factors $\left(\mathrm{C}_{0}, \mathrm{C}_{80}\right)$ proposed by Zhang et al. (2005ab) and Lewis and Schwartz (2006). Additionally, the conversion factor of number to mass fluxes of aerosol (NM) depends on particle density $(\rho)$ and solute weight fraction (x), as defined by Zhang et al. (2005a). SSA emissions

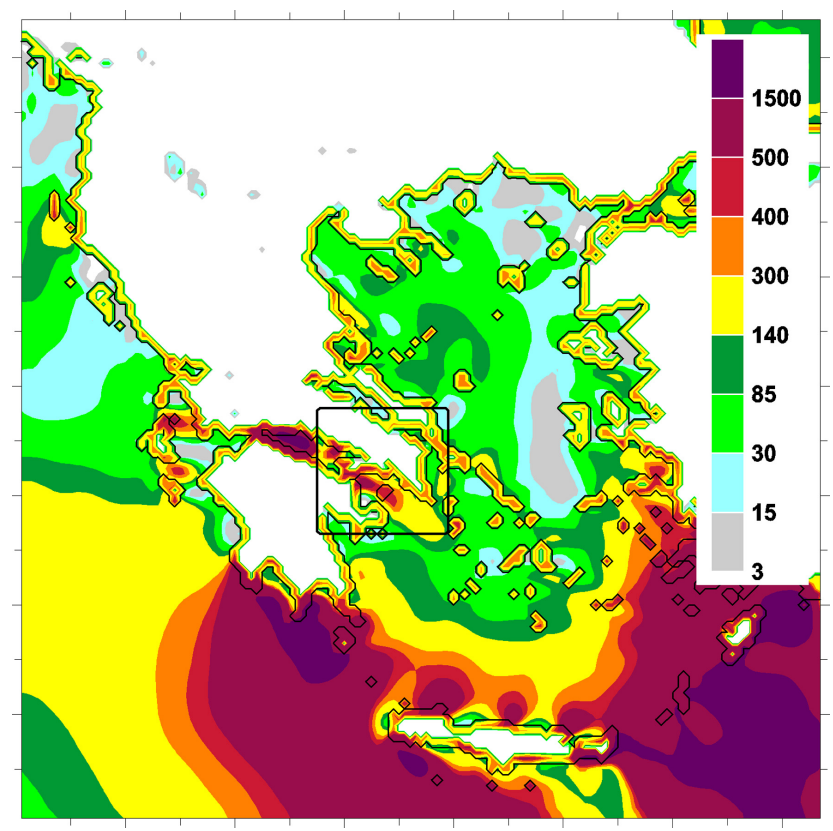

Fig. 4. Spatial distribution of the daily average SSA emission rates $\left(\mathrm{g} \mathrm{km}^{-1} \mathrm{hr}^{-1}\right)$ over Greece. The SSA emissions are distributed uniformly over the coastal computational cells.

were split into the ten size bins of the model application, each having the chemical composition of the dissolved mass in seawater $\left(55 \% \mathrm{Cl}^{-}, 31 \% \mathrm{Na}^{+}, 8 \%\right.$ sea-salt sulfate $\left(\mathrm{ss}-\mathrm{SO}_{4}^{=}\right)$ 
Table 1. SSA source functions and parameters employed by this study.

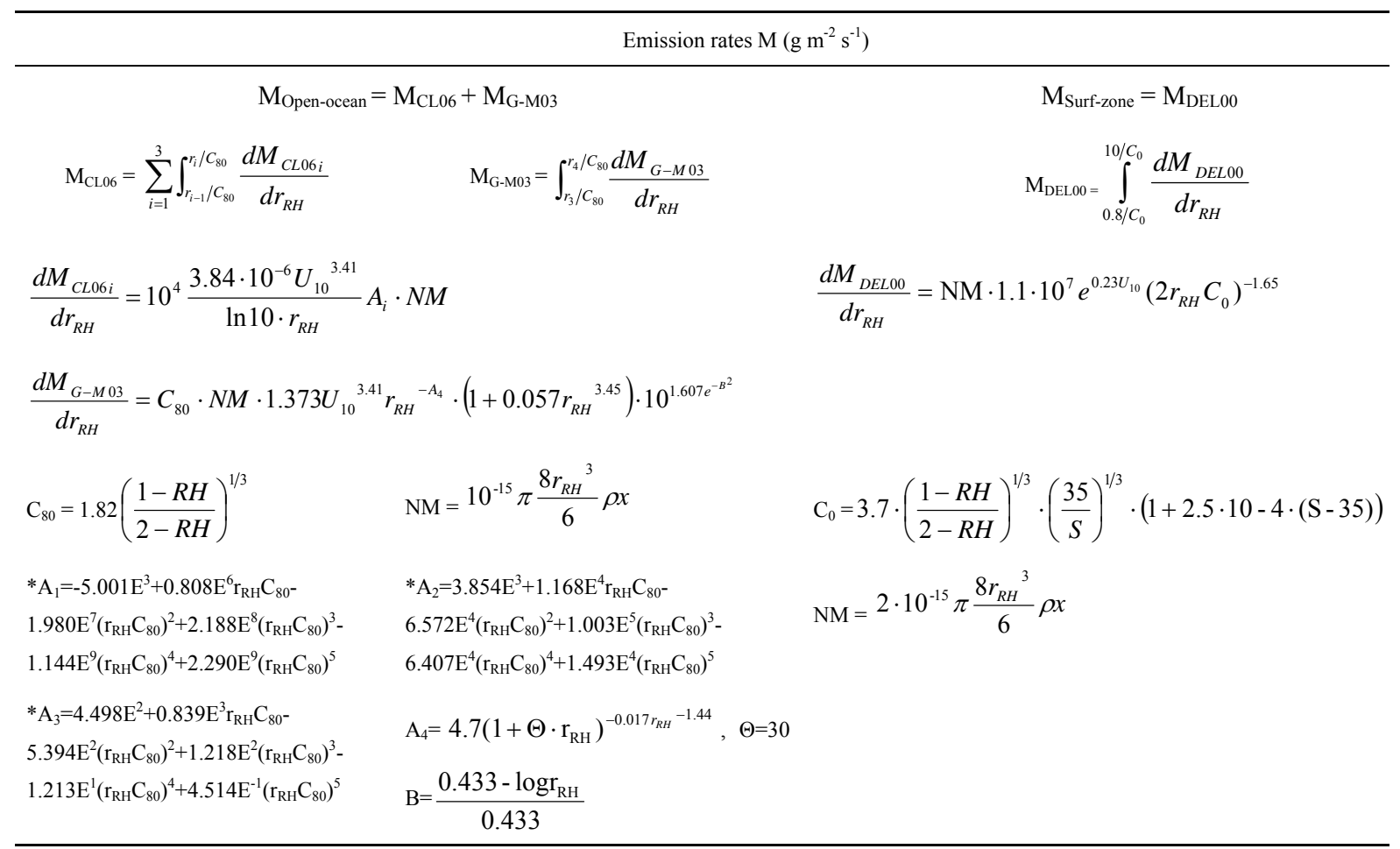

$\mathrm{r}_{R H}=$ particle radius at local/ambient $\mathrm{RH}$ (fraction from 0 to 1 )

$\mathrm{r}_{0}=0.005, \mathrm{r}_{1}=0.065, \mathrm{r}_{2}=0.6, \mathrm{r}_{3}=4, \mathrm{r}_{4}=10(\mu \mathrm{m}), \mathrm{x}=3.1657-19.079 \mathrm{RH}+55.72 \mathrm{RH}^{2}-83.998 \mathrm{RH}^{3}+63.436 \mathrm{RH}^{4}-19.248 \mathrm{RH}^{5}$

$\rho=1000\left(3.8033-16.248 \mathrm{RH}+46.085 \mathrm{RH}^{2}-68.317 \mathrm{RH}^{3}+50.932 \mathrm{RH}^{4}-15.261 \mathrm{RH}^{5}\right)\left(\mathrm{kg} \mathrm{m}^{-3}\right)$

$* \operatorname{read} \mathrm{E}^{x}$ as $10^{x}$

and $6 \%$ the rest ionic species: $\left.4 \% \mathrm{Mg}^{2+}, 1 \% \mathrm{Ca}^{2+}, 1 \% \mathrm{~K}^{+}\right)$, which is acceptable for short times after SSA emission (Seinfeld and Pandis, 1998; Lewis and Schwartz, 2004). The surfzone is assumed to cover $0.25 \%$ of the area of each coastal cell $\left(0.01 \mathrm{~km}^{2}\right.$ for the nested domain), as no other information is available. This rather conservative value could correspond to a surface of $200 \mathrm{~m}$ coastline and $50 \mathrm{~m}$ surf-zone width for the nested domain. The value of $50 \mathrm{~m}$ is considered a mean surf-zone width (De Leeuw et al., 2000; Lewis and Schwartz, 2004).

The SSA emissions algorithm provides the spatial distribution of the hourly rates over the parent and nested domains (Fig. 4). The areas of highest SSA emissions are in the Southern Aegean (around Crete), while small values are predicted in the central and northern Aegean Sea, following the wind speed distribution. SSA PM 10 emissions are similar in magnitude to the rest of the aerosol emission rates (not shown) over the nested domain and are larger over the parent domain. Open-ocean emissions are more important over offshore areas of the parent domain. In the central Aegean Sea, the open-ocean aerosol production is of equivalent importance to the surf-zone mechanism due to the complex and long coastline. Over Attica (in the nested domain), the surf- zone mechanism produces most of the total SSA mass, although the surface from which it originates is small. This is due to the higher intensity of surf-zone compared to the open-ocean aerosol production, combined with a relatively limited open-ocean area inside the nested domain, compared to that of the parent domain.

At a $10 \mathrm{~m}$-wind speed $\left(\mathrm{U}_{10}\right)$ of $13 \mathrm{~m} \mathrm{~s}^{-1}$ open-ocean SSA with diameters greater than $0.6 \mu \mathrm{m}$ and up to $40 \mu \mathrm{m}$ comprises $95 \%$ of the particle mass, but only $2 \%$ of the particle number (Fig. 5). For the same wind speed and surface area, surf-zone SSA emissions are about two orders of magnitude greater than SSA coming from open-ocean. The size range of the calculated surf-produced aerosol is narrow (De Leeuw et al., 2000; Lewis and Schwartz, 2004).

RH affects the size range of SSA emissions for both production mechanisms. In particular, the doubling of RH almost doubles SSA sizes, thus under highly humid conditions (RH greater than $90 \%$ ) little particle mass has diameters less than $1 \mu \mathrm{m}$ which is uniquely produced from the openocean. SSA with diameters greater than $10 \mu \mathrm{m}$ is produced by both mechanisms (and not just from the open-ocean) only when RH is greater than $70 \%$. Larger SSA particles are of minimal importance because production typically does not 


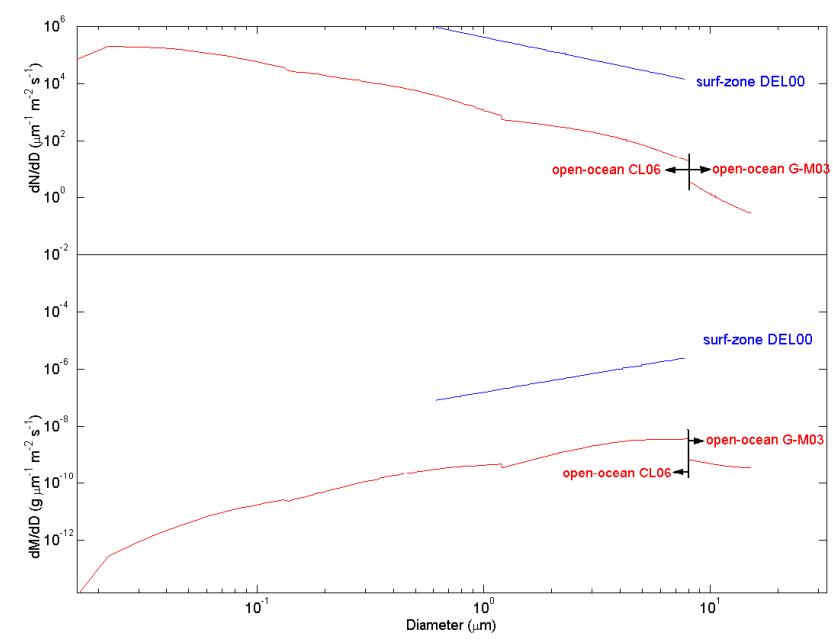

Fig. 5. Sea-salt number ( $N$, upper part) and mass ( $M$, lower part) fluxes as a function of particle size calculated from the applied source functions $\left(\mathrm{U}_{10}=13 \mathrm{~m} \mathrm{~s}^{-1}\right)$, which are shown near the curves. Flux values are for dry particles (at $40 \% \mathrm{RH}$ ). The discontinuity around $8 \mu \mathrm{m}$ is due to the combination of two different source functions (G-M03 and CL06) while the other discontinuities are due to the different polynomials used in the CL06 parameterization.

exceed $40 \mu \mathrm{m}$ (even when RH is $95 \%$ ), but even when it does (spume droplets production) it comes from open-ocean mechanisms and particles deposit rapidly.

Over the surf-zone, minimum $\mathrm{U}_{10}$ values produce about $1 \times 10^{-4} \mathrm{~g} \mathrm{~m}^{-2} \mathrm{~s}^{-1} \mathrm{SSA}$, which exponentially increases up to $1.7 \times 10^{-3} \mathrm{~g} \mathrm{~m}^{-2} \mathrm{~s}^{-1}$ when $\mathrm{U}_{10}$ reaches the maximum calculated coastal value of $12.3 \mathrm{~m} \mathrm{~s}^{-1}$ (Fig. 6). SSA mass fluxes at two coastal sites in California were measured between $3 \times 10^{-4}$ and $1 \times 10^{-3} \mathrm{~g} \mathrm{~m}^{-2} \mathrm{~s}^{-1}$ for wind speeds lower than $9 \mathrm{~m} \mathrm{~s}^{-1}$ (De Leeuw et al., 2000). This similarity is expected, as DEL00 is based on these experimental data. The variation of wind speed affects the open-ocean SSA production more than the surf zone. In particular, although insignificant amounts of SSA mass are emitted during calm conditions, the maximum calculated wind speed $\left(13 \mathrm{~m} \mathrm{~s}^{-1}\right.$, for the selected event) results in $2.5 \times 10^{-6} \mathrm{~g} \mathrm{~m}^{-2} \mathrm{~s}^{-1}$. A prior approximation for open-ocean SSA emissions for the SE Greece (Alexandropoulou and Lazaridis, 2003) gave similar results.

\section{Model results}

The hybrid method is used for calculating mass transfer between the gas and condensed phases in the base-case simulation and is compared to available data from the literature and to the bulk-equilibrium approach. In order to isolate and examine the impact of SSA production on $\mathrm{PM}_{10}$ concentrations and composition, additional simulations are performed with zero SSA emissions. Additional simulations address the relative importance of open-ocean and surf-zone SSA produc-

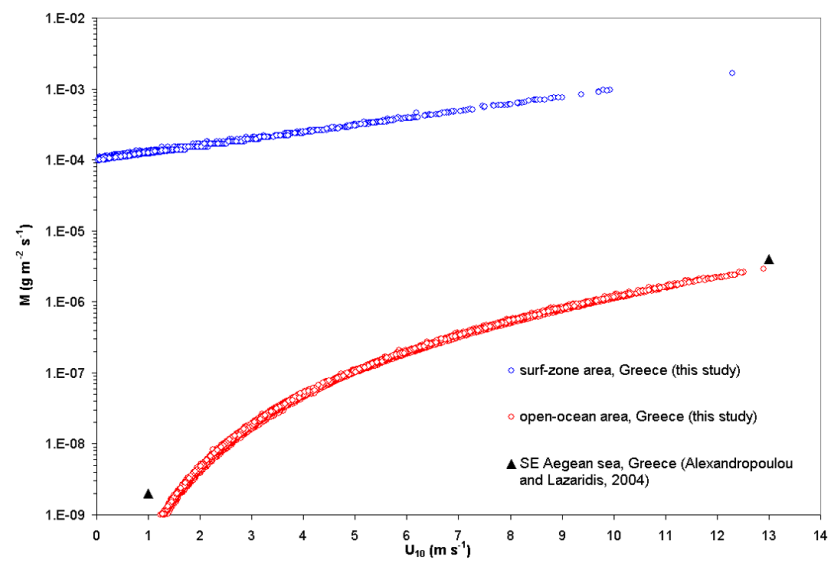

Fig. 6. Wind dependence of SSA emissions, calculated for openocean and surf-zone areas.

tion. To examine the boundary entrainment of SSA into the nested domain from the parent domain, a test case calculated the SSA concentrations, assuming no SSA emissions in the parent domain.

\subsection{Comparison of simulated and observed concentrations}

The lack of measurements of aerosol composition during the simulation period does not allow the evaluation of the model results. The model predictions are compared to averages of measurements during similar periods as an order of magnitude test. The results for $\mathrm{Na}^{+}, \mathrm{Cl}^{-}$and sulfate (Fig. 7a, b, c, f) are encouraging. For example, the simulated average $\mathrm{PM}_{10}$ $\mathrm{Na}^{+}$concentrations in central Athens and Crete (Finokalia) are $0.8 \mu \mathrm{g} \mathrm{m}^{-3}$ and $2.3 \mu \mathrm{g} \mathrm{m}^{-3}$, respectively, values consistent with measured values in previous field campaigns (Table 2). Chloride and sulfate predictions and observations are also similar to the observed. These results suggest that the SSA emissions algorithms provide reasonable mass fluxes, as also indicated in Nolte et al. (2008) for a similar sea-salt modeling application.

Nitrate and ammonium mass is underestimated (Fig. 7d, e). Simulated $\mathrm{PM}_{10}$ nitrate average values are less than $1 \mu \mathrm{g} \mathrm{m}^{-3}$, on average, while available measurements in similar summer periods suggest greater values (Table 2). At the same time the model predicts high concentrations of $\mathrm{HNO}_{3}$ in the gas phase (around $5 \mu \mathrm{g} \mathrm{m}^{-3}$, Fig. $7 \mathrm{~g}$ ) while observations indicate much lower values. The overprediction of $\mathrm{HNO}_{3}$ and the underprediction of ammonium nitrate suggest that gas-to-particle conversion is underestimated. Ammonium predictions are around $1 \mu \mathrm{g} \mathrm{m}^{-3}$, for the whole $\mathrm{PM}_{10}$ mass, while observations exceed $2 \mu \mathrm{g} \mathrm{m}^{-3}$ even for $\mathrm{PM}_{2.5}$, alone (Athens). Uncertainties in $\mathrm{NH}_{3}$ emissions are believed to play an important role in the above discrepancies. Ammonia predictions (Fig. $7 \mathrm{~h}$ ) are extremely low (typically around $10^{-1} \mu \mathrm{g} \mathrm{m}^{-3}$ ), and this leads to negligible production of fine $\mathrm{NH}_{4} \mathrm{NO}_{3}$, as also found by Athanasopoulou et al. (2005). 

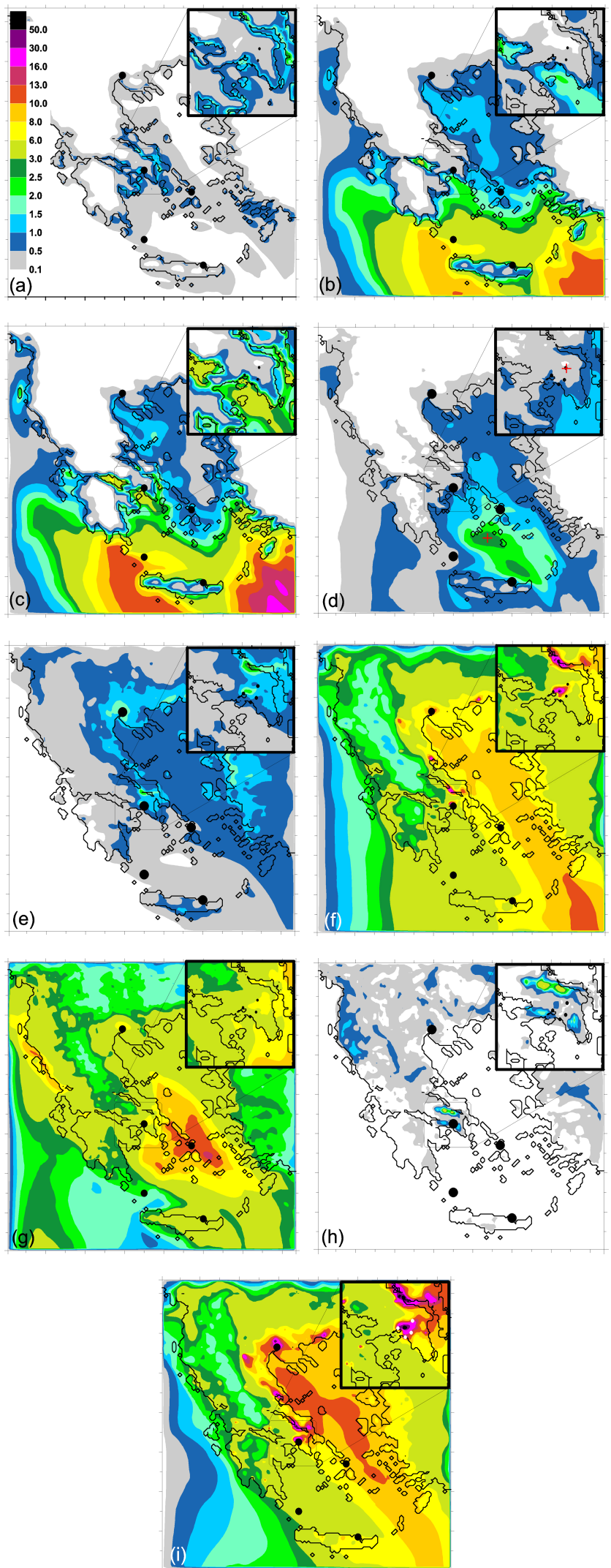

Fig. 7. Spatial distribution of average daily $\mathrm{PM}_{10}$ species concentrations $\left(\mu \mathrm{g} \mathrm{m}^{-3}\right)$ over Greece: (a) surfzone sodium $\left(\mathrm{Na}^{+}\right)$, (b) open-ocean $\mathrm{Na}^{+}$, (c) chloride $\left(\mathrm{Cl}^{-}\right)$, (d) nitrate $\left(\mathrm{NO}_{3}^{-}\right)$, (e) total ammonium $\left(\mathrm{NH}_{4}{ }^{+}\right)$, (f) total sulfate $\left(\mathrm{SO}_{4}{ }^{-}\right)$, (g) nitric acid $\left(\mathrm{HNO}_{3}\right)$, (h) ammonia (NH3), (i) non-SSA PM 10 (inorganic and carbon). 
Table 2. Inorganic aerosol and gaseous species concentrations $\left(\mu \mathrm{g} \mathrm{m}^{-3}\right)$ observed during other studies and predicted from the present study. Data in parentheses show either minimum and maximum values ( 2 numbers) or the standard deviation of the average value ( 1 number).

\begin{tabular}{|c|c|c|c|c|c|c|c|c|c|c|c|}
\hline Location & Time period & $\mathrm{Cl}^{-}$ & $\mathrm{Na}^{+}$ & $\mathrm{SO}_{4}^{=}$ & $\mathrm{NO}_{3}^{-}$ & $\mathrm{NH}_{4}^{+}$ & $\mathrm{HNO}_{3}$ & $\mathrm{NH}_{3}$ & $\mathrm{HCl}$ & Wind $\left(\mathrm{m} \mathrm{s}^{-1}\right)$ & Reference \\
\hline \multirow[t]{7}{*}{ Athens } & 03/1995-03/1996 & $3.7(3.1)$ & $2.6(3)$ & $9.8(4.2)$ & $2.3(2)$ & $2.1(1.4)$ & - & - & - & SE-SW & (Siskos et al., 2001) \\
\hline & $15 / 04-12 / 06 / 1987^{1}$ & $0.3(0-1.3)$ & $0.4(0-0.2)$ & $10.4(4-24)$ & $2(0.5-5)$ & - & - & - & - & $2(0.3-10.3)$ & (Scheff and Valiozis, 1990) \\
\hline & 29/08-16/09/1994*\# & 0.5 & 0.5 & $5.5(3-10)$ & $2(1-5)$ & $1.5(0.5-4)$ & $1.5(0.6-3)$ & & $0.5(0.1-0.8)$ & $(1-14)$ & (Eleftheriadis et al., 1998a) \\
\hline & $25 / 05 / 1990$ & - & - & - & - & - & - & 2.5 & - & - & (Sotiropoulou et al., 2003) \\
\hline & 03-04/1989 & - & - & - & - & - & - & 2.4 & - & _- & (Kirkitsos and Sikiotis, 1993) \\
\hline & $12 / 2002-11 / 2003^{1}$ & - & - & - & 3.1 & - & 1.6 & - & - & - & \multirow{2}{*}{$\begin{array}{l}\text { (Ferm et al., 2005) } \\
\text { this study }\end{array}$} \\
\hline & OA $(24 / 06 / 1998)^{3}$ & $0.6(0.3)$ & $0.8(0.2)$ & $5.8(1)$ & $0.4(0.4)$ & $1(0.5)$ & $5.1(1.3)$ & $0.2(0.2)$ & $0.7(0.2)$ & $1.9(0.8)$ & \\
\hline Piraeus & OA $(24 / 06 / 1998)^{3}$ & $2.6(1)$ & $2(0.5)$ & $4.9(1.2)$ & $0.5(0.4)$ & $0.7(0.3)$ & $4(1.8)$ & $0.4(0.5)$ & $0.9(0.4)$ & $2.6(0.9)$ & \multirow{4}{*}{$\begin{array}{c}\text { this study } \\
\text { (Colbeck et al., 2002) }\end{array}$} \\
\hline Piraeus (Castella) & $17 / 07-06 / 08 / 1997^{* \#}$ & 0.3 & 0.7 & 4 & 1.5 & 2.5 & 2 & 2 & 1.2 & - & \\
\hline N.Suburb (Ag. Stefanos) & $17 / 07-06 / 08 / 1997^{* \#}$ & 0.5 & 1 & 8 & 3 & 3.5 & 2.5 & 2 & 4.3 & - & \\
\hline N. Suburb (Thrakomakedones) & OA $(24 / 06 / 1998)^{3}$ & $0.1(0.1)$ & $0.4(0.2)$ & $7.4(2.4)$ & $0.1(0.1)$ & $1.2(0.3)$ & $6.3(3.1)$ & $0.1(0.1)$ & $0.6(0.2)$ & $2.2(1.3)$ & \\
\hline \multirow[t]{2}{*}{ Eleusis } & 2-year period ${ }^{2}$ & $4(3.7)$ & $1.6(0.6)$ & $8(9.3)$ & $3.1(3.2)$ & - & - & - & - & - & \multirow{2}{*}{$\begin{array}{l}\text { (Torfs and Grieken, 1997) } \\
\text { this study }\end{array}$} \\
\hline & OA $(24 / 06 / 1998)^{3}$ & $2.4(1.2)$ & $2(0.7)$ & $11.7(6.3)$ & $0.6(0.6)$ & $1.5(1.2)$ & $5.3(1.5)$ & $0.3(0.4)$ & $1.2(0.4)$ & $1.9(1.2)$ & \\
\hline \multirow[t]{5}{*}{ Thesaloniki } & $07 / 1997-07 / 1998^{3}$ & $0.9(0.5)$ & $0.6(0.6)$ & $4.8(2)$ & $2.8(1.4)$ & $2.7(1.6)$ & - & - & - & - & \multirow{5}{*}{$\begin{array}{l}\text { (Anatolaki and Tsitouridou, 2007) } \\
\text { this study }\end{array}$} \\
\hline & $07 / 1997-07 / 1998^{3}$ & $1.4(0.8)$ & $0.6(0.5)$ & $7.2(5.8)$ & $3.4(1.9)$ & $3.5(2.3)$ & - & - & - & - & \\
\hline & $07 / 1997-07 / 1998^{3}$ & $1(0.7)$ & $1(1.1)$ & $7.3(5.8)$ & $4(2.1)$ & $4.2(3.2)$ & - & - & - & - & \\
\hline & $04 / 2002-03 / 2003^{4}$ & - & - & $6.6(3.1)$ & $2.9(2.7)$ & $2.7(2.1)$ & $0.8(0.5)$ & $2.3(1.5)$ & $0.3(0.3)$ & weak SW, NW & \\
\hline & OA $(24 / 06 / 1998)^{3}$ & $0.2(0.1)$ & $0.6(0.2)$ & $13.4(2.8)$ & $0.2(0.3)$ & $2.2(0.9)$ & $6.5(2.3)$ & $0.2(0.3)$ & $0.7(0.2)$ & $1.8(0.9)$ & \\
\hline \multirow[t]{4}{*}{ Aegean sea } & OA $(24 / 06 / 1998)^{3}$ & $6.7(4.7)$ & $5.2(3.2)$ & $5(0.6)$ & $0.4(0.3)$ & $0.2(0.2)$ & $2.1(0.4)$ & $0(0)$ & $2.4(0.9)$ & $5(1.8)$ & \multirow{4}{*}{$\begin{array}{c}\text { this study } \\
\text { (Eleftheriadis et al., 2006) } \\
\text { (Lazaridis et al., 2006) }\end{array}$} \\
\hline & $25-29 / 07 / 2000^{*}$ & $0.01(0.1)$ & $0.1(0.1)$ & $10.1(1.1)$ & $0.2(0.0)$ & $7.2(2.9)$ & - & - & - & 3.7 & \\
\hline & $25-30 / 07 / 2000^{*}$ & 2 & - & 8.5 & 2.9 & 1.5 & - & - & - & - & \\
\hline & $26-29 / 07 / 2000^{3}$ & 0.6 & 0.8 & 9.3 & 3.2 & 5.7 & - & - & - & - & \\
\hline \multirow[t]{7}{*}{ Finokalia } & $13-16 / 07 / 2000^{3}$ & 3.1 & 4.1 & 4.2 & 3.4 & 1 & - & - & - & - & \multirow[t]{2}{*}{ (Smolik et al., 2003) } \\
\hline & $26-30 / 07 / 2000^{3}$ & 0.2 & 0.6 & 8.2 & 2 & 3.7 & - & - & - & - & \\
\hline & $10-31 / 07 / 2000^{5}$ & $2.3(0.4)$ & $2(0.3)$ & $6.9(0.9)$ & $2.75(0.41)$ & $2.4(0.4)$ & - & - & - & - & (Lazaridis et al., 2006); (Bardouki et al., 2003) \\
\hline & $10 / 1996-09 / 1999$ & - & - & - & $1.7(0.8)$ & $0.9(0.4)$ & $1.2(0.8)$ & $0.2(0.1)$ & - & - & $\begin{array}{l}\text { (Kouvarakis et al., 2001) } \\
\text { (1) }\end{array}$ \\
\hline & $1-6 / 08 / 2001^{6 / *}$ & $0.1 / 2.1$ & $0.12 / 2.28$ & $3.7 / 0.81$ & $0.11 / 2.12$ & $1.09 / 0.05$ & 0.69 & 0.63 & 2.4 & moderate N-NW & (Metzger et al., 2006) \\
\hline & $25-29 / 07 / 2000^{*}$ & $0.1(0.1)$ & $0.1(0.0)$ & $6.9(1.7)$ & $0.27(0.09)$ & $3.7(0.7)$ & - & - & - & 3.7 & (Eleftheriadis et al., 2006) \\
\hline & OA $(24 / 06 / 1998)^{3}$ & $2.5(1)$ & $2.3(0.8)$ & $5.3(1)$ & $0.9(0.3)$ & $0.4(0.1)$ & $4.1(1.3)$ & $0.1(0)$ & $0.9(0.2)$ & $4(2)$ & this study \\
\hline \multirow[b]{2}{*}{ Patras } & OA $(24 / 06 / 1998)^{3}$ & $0.7(0.4)$ & $0.9(0.3)$ & $3.8(0.5)$ & $0.4(0.1)$ & $0.4(0.2)$ & $7(1.3)$ & 0 (0) & $1.1(0.3)$ & & this study \\
\hline & $11 / 1995-08 / 1996$ & - & - & - & $0.6-1.59$ & $1.7-3.7$ & $1.6-4.2$ & $2-4.4$ & - & - & (Danalatos and Glavas, 1999) \\
\hline \multirow{2}{*}{ Rio (10 km NE of Patras) } & $14-19 / 06 / 1996$ & - & - & - & $0.7(0.3)$ & - & $2.7(1.1)$ & - & - & 8 & (Danalatos and Glavas, 2002) \\
\hline & $11 / 2004-11 / 2005^{1}$ & 0.1 & 0.1 & 3.2 & 0.4 & 1.6 & - & - & - & - & (Glavas et al., 2008) \\
\hline \multirow[t]{2}{*}{ Delos isl. } & OA $(24 / 06 / 1998)^{3}$ & $0.9(0.4)$ & $1.6(0.4)$ & $7.1(1.3)$ & $1.6(0.3)$ & $0.4(0.2)$ & $12.5(2)$ & $0(\mathbf{0})$ & $2.3(0.4)$ & $2.8(1.1)$ & this study \\
\hline & $07 / 95^{*}$ & $10.63(2.72)$ & $12.9(1.82)$ & 8.94 & - & - & - & - & - & 10 & (Chabas and Lefevre, 2000) \\
\hline
\end{tabular}

Average ion concentration in: ${ }^{1} \mathrm{PM}_{2.5}$ mass; ${ }^{2}$ in $\mathrm{PM}_{2}$ mass; ${ }^{3}$ in $\mathrm{PM}_{10}$ mass; ${ }^{4}$ in $\mathrm{PM}_{5}$ mass; ${ }^{5}$ in $\mathrm{PM}_{15}$ mass; 6 in $\mathrm{PM}_{1.2}$ mass * Unidentified fraction of aerosol mass measured; ${ }^{\#}$ Rough mean approximations from data shown in figure plots

To study the sensitivity of the model predictions to $\mathrm{NH}_{3}$, an additional simulation was conducted increasing the agricultural ammonia emissions by a factor of 10 for the parent domain. This adjustment substantially improves the model performance in terms of $\mathrm{NH}_{3}$, aerosol ammonium and nitrate. Predicted ammonia concentrations approach observed values (about $2 \mu \mathrm{g} \mathrm{m}^{-3}$ ) over most of the sites of interest. Sulfate concentrations are slightly affected, as $\left(\mathrm{NH}_{4}\right)_{2} \mathrm{SO}_{4}$ production is limited by available $\mathrm{H}_{2} \mathrm{SO}_{4}$. Nitrate and ammonium predictions improve at downwind areas of the high $\mathrm{NH}_{3}$ emissions.

Reasonable $\mathrm{NO}_{3}^{-}$concentrations (mainly coarse mass, around $3 \mu \mathrm{g} \mathrm{m}^{-3}$ ) are predicted over the marine area North of Crete in the base-case simulation (Fig. 8a). Aerosol composition in this area is dominated by the marine-affected species and its daily variation follows the wind speed fluctuation (maximum values over night). The high marine-related $\mathrm{NO}_{3}^{-}$and an absence of submicrometer $\mathrm{NO}_{3}^{-}$is also seen in other studies over marine areas (Bardouki et al., 2003; Eleftheriadis et al., 1998a; 1999).

The above results suggest that the $\mathrm{SSA}, \mathrm{SO}_{2}$ and $\mathrm{NO}_{\mathrm{x}}$ emissions, and the oxidation of $\mathrm{SO}_{2}$ and $\mathrm{NO}_{\mathrm{x}}$, are simulated reasonably well by the model, but that the ammonia emissions are low. The ammonia sensitivity test indicates that

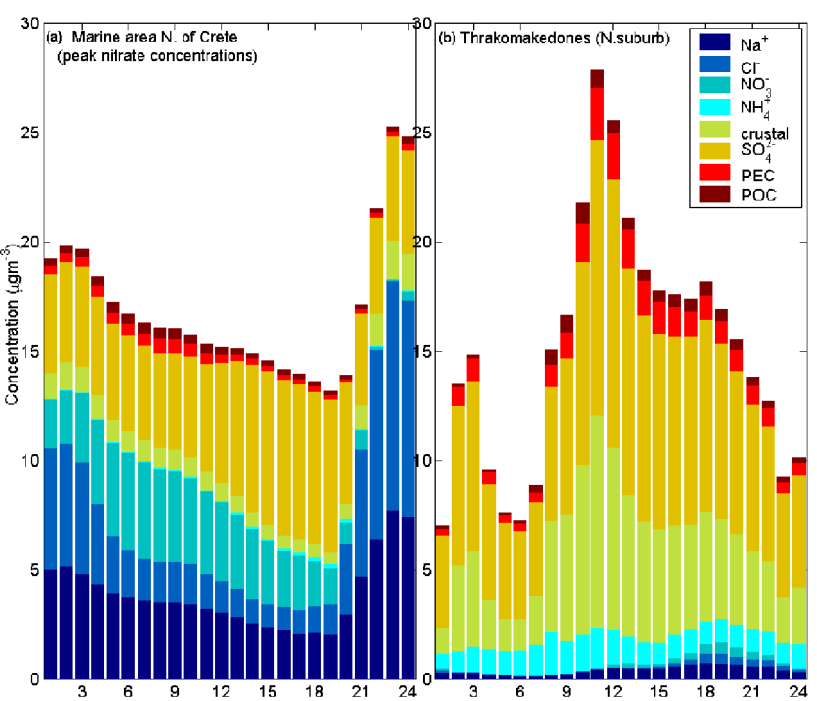

Fig. 8. Daily variability of the PM10 aerosol composition over: (a) the marine area North of Crete and (b) Thrakomakedones. The sites are indicated by red crosses in Fig. 7d. 


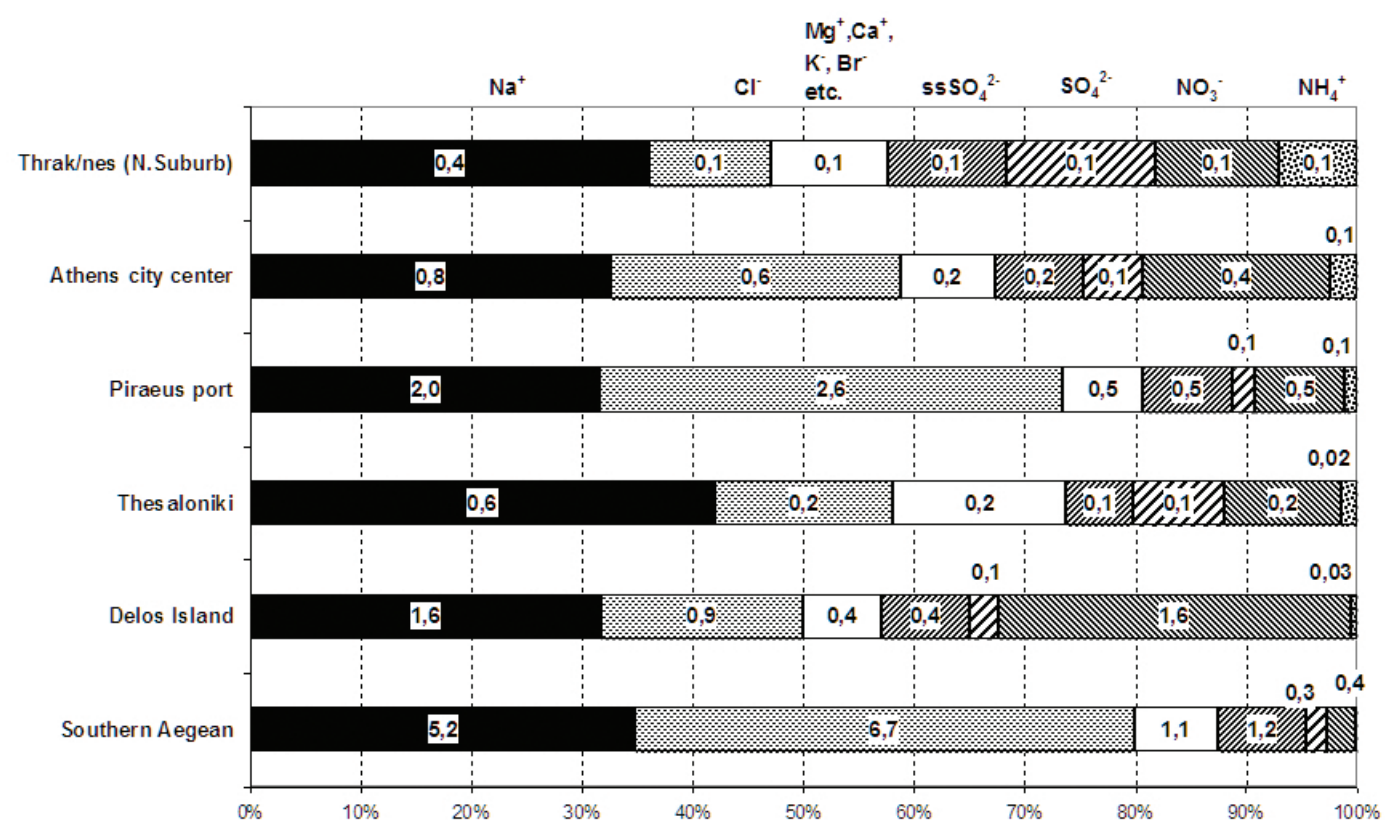

Fig. 9. Chemical speciation of the SSA-derived mass in the $\mathrm{PM}_{10}$ concentrations at selected sites (the difference in $\mathrm{PM}_{10}$ results between the base-case simulation and the simulation without SSA emissions, expressed as a percentage of the base-case concentrations). Chemical species are shown at the top. Values inside bars are the daily average concentrations $\left(\mu \mathrm{g} \mathrm{m}^{-3}\right)$ of each species

original $\mathrm{NH}_{3}$ emission rates should be increased both for the parent and the nested domains. Uncertainties of local dust emissions and their interaction with nitric acid may also be contributing to the nitrate underestimation (Hien et al., 2005; Hodzic et al., 2006; Nolte et al., 2008).

\subsection{Impact of SSA on aerosol concentrations and composi- tion}

The difference in $\mathrm{PM}_{10}$ results between the base-case simulation and the simulation without SSA emissions (expressed as a percentage of the base-case concentrations) provides both the direct (addition of sea-salt) and indirect (heterogeneous reactions with sulfuric and nitric acid) effects of SSA in the $\mathrm{PM}_{10}$ concentrations in the area. Marine-affected $\mathrm{PM}_{10}$ is highest in the south (around $30 \mu \mathrm{g} \mathrm{m}^{-3}$ ), with the rest of the mass mainly in the form of sulfate and carbon (Fig. 7f, i). At coastal sites, the fraction of $\mathrm{PM}_{10}$ from SSA and its reaction products ranges from 20 to $60 \%$ and is calculated $25 \%$ $\left(6.5 \mu \mathrm{g} \mathrm{m}^{-3}\right)$ at the coastal site of Piraeus. Experimental data $\left(\mathrm{Na}^{+}, \mathrm{Cl}^{-}\right.$and $\mathrm{ss}_{-} \mathrm{SO}_{4}^{=}$species) from a coastal site in Spain (Salvador et al., 2007) indicate a similar $\mathrm{PM}_{10}$ contribution. SSA production also affects the aerosol inland, especially under onshore winds. For example, marine-related aerosol $\left(2.5 \mu \mathrm{g} \mathrm{m}^{-3}\right)$ comprises $15 \%$ of the daily average $\mathrm{PM}_{10}$ mass $9 \mathrm{~km}$ inland in the Athens basin. This contribution drops to $1 \mu \mathrm{g} \mathrm{m}^{-3}$ representing $7 \%$ of $\mathrm{PM}_{10}$ at Thrakomakedones, $27 \mathrm{~km}$ inland. SSA contributions to $\mathrm{PM}_{2.5}$ mass are much lower and in the Athens basin are around 10\%.
Sodium is well suited to characterize SSA as it completely resides in the condensed phase and is dominated by sea emissions. Offshore areas away from the coastline are primarily affected by the open-ocean aerosol production mechanism. Over coastal areas, surf-zone mechanism is also important (Cyclades islands) or more important (Attica coastal zone) than open-ocean aerosol production. Over inland areas affected by stable onshore winds (e.g. Attica) open-ocean and surf-zone mechanisms contribute almost equally on aerosol production (Fig. 7a, b).

Low emission offshore areas away from the coastline find the chemical composition of the portion of aerosol mass linked to SSA, mainly $(95 \%)$ as primary sea-salt ions $\left(\mathrm{Na}^{+}\right.$, $\mathrm{Cl}^{-}$, ss- $\mathrm{SO}_{4}^{=}, \mathrm{Mg}^{2+}, \mathrm{Ca}^{2+}, \mathrm{K}^{+}, \mathrm{Br}^{-}$etc), as chlorine remains mostly in the condensed phase (southern Aegean site in Fig. 9). Secondary aerosol production from reactions between SSA and nitric and sulfuric acid is minimal in these areas. Alternatively, in the Cyclades area (e.g., Delos island in Fig. 9), shipping routes are quite dense (Fig. 2) resulting in significant production of $\mathrm{HNO}_{3}$ which reacts with SSA forming $\mathrm{NaNO}_{3}$. Here, primary sea-salt ions constitute $64 \%$ of marine-related $\mathrm{PM}_{10}$, and aerosol $\mathrm{NO}_{3}^{-}$another $32 \%$. Aerosol $\mathrm{Cl}^{-}$is displaced and the resulting $\mathrm{HCl}$ is lost by dry deposition. In the Attica peninsula, marine-related secondary species $\left(\mathrm{NO}_{3}^{-}, \mathrm{SO}_{4}^{=}\right.$and $\left.\mathrm{NH}_{4}^{+}\right)$take lower concentration values as we move further north and inland, but are of greater importance, reaching $32 \%$ of the marine-affected aerosol at Thrakomakedones (N. suburb). Simulated peak nitrate concentrations $\left(4.5 \mu \mathrm{g} \mathrm{m}^{-3}\right)$ occur over the marine area north of 

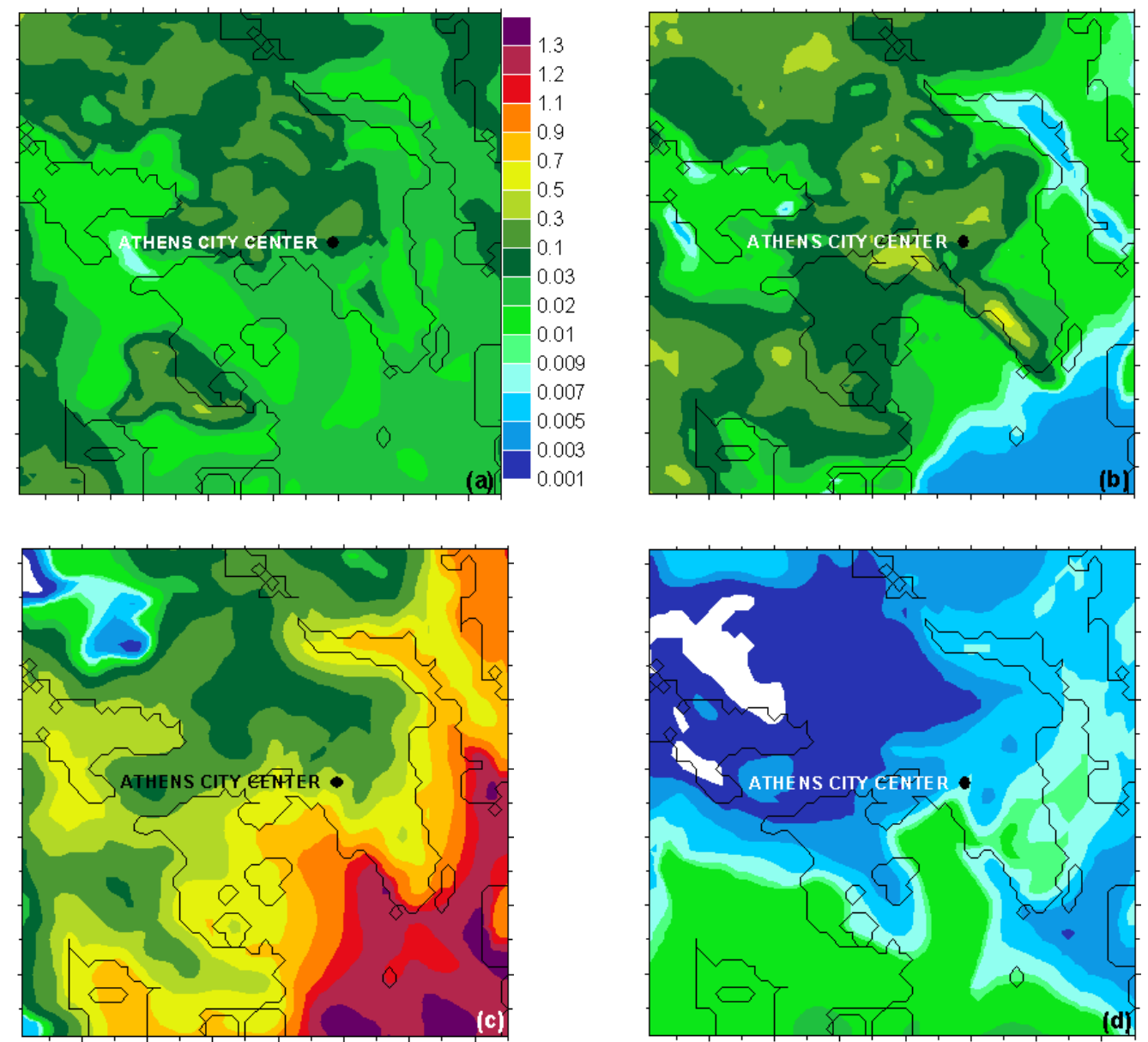

Fig. 10. Daily average fine (upper part) and coarse (lower part) nitrate concentration fields $\left(\mu \mathrm{g} \mathrm{m}^{-3}\right)$ in the nested domain. (a) and (c): hybrid (base-case) approach, (b) and (d): bulk-equilibrium approach.

Crete due to high local $\mathrm{NO}_{\mathrm{x}}$ emissions from shipping, reduced deposition and the availability of $\mathrm{Na}+$, especially during early morning hours (Fig. 7d, Fig. 8a). As the day passes, peak values decrease by 2 to $3 \mu \mathrm{g} \mathrm{m}^{-3}$, but expand spatially. Winds transport nitrate into Attica from the southern sector (embedded rectangle in Fig. 7d) during the whole daylight period, leading to an effective penetration inland with elevated values during the evening hours (Fig. 8b). Peaks near Eleusis and at Evoicos Gulf, coincide with high $\mathrm{Na}^{+}$ratios and local industrial sources emitting $\mathrm{NO}_{\mathrm{x}}$ (Fig. 2). Use of the finer grid in this region allowed capturing the importance of surf-zone SSA production and relatively rapid chemical dynamics and gas-to-particle conversion near the coast.

Inclusion of SSA can also impact the formation of ammonium nitrate when liquid aerosol is present. Over Thessaloniki, in the early morning during rush hour, significantly more ammonium nitrate is predicted to be formed when SSA is included, because the presence of additional ions in the solution reduces the ammonium nitrate equilibrium constant, shifts its' partitioning towards the particulate phase and in- creases the ammonium and nitrate concentrations in the liquid particles. The phenomenon is especially pronounced in the Thessaloniki area due to the stably high RH over Thesaloniki gulf (around 90\%) during the simulation period.

The identification of the areas predicted to be affected by SSA during the present work could be taken into account when designing field campaigns fort he study of air quality in the the Aegean sea. The Cyclades islands provide appropriate sites for measuring the relevant aerosol species (sodium, nitrate etc.), and studying the interaction between ship pollution and SSA, as they belong to the peak area of anthropogenic-SSA interaction and shipping lanes are quite dense. Delos island is especially promising as it is near the maximum ship emissions, and has very low local anthropogenic emissions. These measurements should take place at the same time, as measurements in the Attica peninsula.

\subsection{Sensitivity to mass transfer between phases}

Bulk $\mathrm{PM}_{10}$ predictions are affected by the treatment of mass transfer between the gas and condensed phases, but can have 
an important effect on specific constituents. The difference in the inorganic $\mathrm{PM}_{10}$ results of the base-case simulation and the simulation with the bulk-equilibrium approach (expressed as a percentage of the base-case concentrations) reaches 10\% over the central Aegean area (not shown), coinciding with elevated aerosol nitrate concentrations (Fig. 10). The instant equilibration dictated by the equilibrium approach fails to accurately represent the competition between the fine and coarse particles for the condensing sulphuric and nitric acid especially in the marine areas of the modelling domain. In the bulk equilibrium approach the sulphuric acid reacts with the larger $\mathrm{NaCl}$ particles forming sodium sulphate. This reaction leaves only small amounts of alkaline $\mathrm{NaCl}$ available to react with the nitric acid vapour and therefore the equilibrium approach predicts relatively small amounts of coarse nitrate. In the marine areas, the concentrations of ammonia are low, so there is also little ammonium nitrate formed in the fine particles. Therefore, in the marine areas the bulk equilibrium approach predicts significantly less nitrate than the hybrid approach. This leads to large differences (around 90\%) in inorganic $\mathrm{PM}_{10}$ nitrate concentrations between the base-case simulation and that with the bulkequilibrium approach over most of the marine-affected domain (not shown).

In the urban parts of the domain the bulk-equilibrium approach continues to seriously under predict the coarse nitrate concentration (Fig. 10). In particular, the daily average value of $\mathrm{PM}_{10} \mathrm{NO}_{3}^{-}$concentration in the Athens city center is predicted to be $0.1 \mu \mathrm{g} \mathrm{m}^{-3}$. The dynamic mass-transfer between phases results in a quadrupling of aerosol $\mathrm{NO}_{3}^{-}$at the city center, similar to Capaldo et al. (2000) for Los Angeles. This discrepancy is mainly attributable to the coarse nitrate mass differences and reaches two orders of magnitude. The bulk-equilibrium method predicts slightly higher concentrations of fine nitrate due to the accumulation of the condensing material in the smallest bins, as seen by Capaldo et al. (2000). $\mathrm{PM}_{10-40}$ differences are negligible for nitrate due to low $\mathrm{PM}_{10-40}$ emissions.

Previous studies have recommended $1 \mu \mathrm{m}$ as the cut-off diameter between the equilibrium and dynamic approach (Capaldo et al., 2000; Koo et al., 2003; Gaydos et al., 2003). Our base-case results use an increased threshold $(2.5 \mu \mathrm{m})$, in order to reduce the computational cost of the model. A sensitivity test using of lower cut-off $(1 \mu \mathrm{m})$ resulted in small (less than $0.5 \mu \mathrm{g} \mathrm{m}^{-3}$ ) changes in average nitrate concentrations. This effect of the cut-off diameter is expected to be different when ammonia emissions are increased, and therefore future applications of the model should probably use the recommended lower threshold diameter.

\subsection{Local versus regional SSA contribution}

The use of a greater parent domain in which the area of interest is nested, is found necessary during this event, as the transport of SSA from its boundaries is temporally and spa- tially variable. A significant fraction of the sea-salt over the urban area is produced in marine areas relatively far from it. The southern and western boundaries contribute most to total SSA boundary penetration (from $0.2 \mu \mathrm{g} \mathrm{m}^{-3}$ over land to $23 \mu \mathrm{g} \mathrm{m}^{-3}$ over sea), and is found to vary diurnally with the winds. The northern and the eastern boundaries contribute less to total SSA boundary penetration, although higher values are expected to appear during more intense wind regimes over Greece, such as the frequently occurring NE etesian.

If medium or low resolution Chemical Transport Models are used to describe sea-salt production, transport and chemistry in an area where the anthropogenic emissions are more spatially homogeneous than in this work nesting would not have such a significant effect. In our case it is the existence of the quite different scales (small length-scale for the description of Athens together with the larger scale for transport of sea-salt from the Aegean to Athens) that makes necessary the nested description. If the appropriate coastline length is used in each cell together with the appropriate meteorological fields, then the SSA representation would be relatively independent of the resolution (at least in the $1-10 \mathrm{~km}$ scales investigated here).

\section{Conclusions}

Use of SSA emissions in a simulation of atmospheric chemical dynamics over Greece led to greater $\mathrm{PM}_{10}$ levels than these predicted when excluding such emissions and allowed investigation of the importance of gas-to-particle conversion in areas with an extended Archipelago. SSA emissions are comparable to all other $\mathrm{PM}_{10}$ emissions in this case. Over much of the domain, open-ocean emissions contribute most to SSA, but near and over land, surf-zone emissions become important. SSA further impacts $\mathrm{PM}_{10}$ by reactions with nitric and sulfuric acid, displacing chloride.

The use of a greater parent domain in which the area of interest is nested, is found necessary during this event, as the transport of SSA from its boundaries is temporally and spatially variable. Above land, SSA comprised even $60 \%$ of the $\mathrm{PM}_{10}$ but only $10 \%$ of the $\mathrm{PM}_{2.5}$, near the coast, decreasing rapidly inland. For example, near the Athens coast (Piraeus port), of the $27 \mu \mathrm{g} \mathrm{m}^{-3}$ total $\mathrm{PM}_{10}, 6.5 \mu \mathrm{g} \mathrm{m}^{-3}$ was due to SSA emissions. At Thrakomakedones $27 \mathrm{~km}$ inland, this dropped to $1 \mu \mathrm{g} \mathrm{m}^{-3}$. Nitric and sulfuric acid displacement was found to be important both above land and over the sea. Interestingly, the highest nitrate levels were found over and downwind the shipping lanes in the Aegean due to $\mathrm{NO}_{\mathrm{x}}$ emission oxidation forming $\mathrm{HNO}_{3}$, along with the relatively low deposition rates, allowing ample time for the rate-limited mass transfer through the displacement of chloride. The long residence time of the aerosol nitrate formed over the sea allows this peak to be transported northward towards Athens. The nested approach contributes to the simulation both of the finer-scale processes (e.g., surf-zone SSA 
production and near-coastal gas-aerosol interactions), and of the effects of sea-salt production, chemical transformation and transport from the Aegean to the urban area of interest (Athens).

While the simulated $\mathrm{Na}^{+}, \mathrm{Cl}^{-}$and $\mathrm{SO}_{4}^{=}$levels agreed with the averages of observations during similar periods, suggesting the SSA emissions algorithms used are providing reasonable estimates, the simulated nitrate and ammonium levels are low. Summing simulated $\mathrm{NO}_{3}^{-}$and $\mathrm{HNO}_{3}(\mathrm{~g}$ ) found that ample nitrate is formed, but gas-to-particle conversion is underestimated. This is traced to very low levels of total ammonia (ammonium + ammonia), suggesting a bias in the emissions, also identified by a sensitivity run. Further, comparing the size distribution of simulated nitrate and ammonium to observations provides further evidence it is the lack of ammonium nitrate formation that leads to a low bias in the simulated levels of those two aerosol components. Improvement of the ammonia emission inventory for Greece (absolute amounts, spatial and temporal resolution) is needed.

Examining the size distribution of both SSA emissions and aerosol concentrations shows that SSA mainly affects the coarse mass, thus the adoption of a gas-to-particle mass transfer scheme is necessary. Using a hybrid scheme that combines the equilibrium approach for $\mathrm{PM}_{2.5}$ with a dynamic approach for coarser particles, led to a quadrupling of aerosol nitrate in the Athens city center versus use of a pure equilibrium approach. A sensitivity test using of lower cutoff $(1 \mu \mathrm{m})$ resulted in small (less than $0.5 \mu \mathrm{g} \mathrm{m}^{-3}$ ) changes in average nitrate concentrations, given the low ammonia emission rates.

The lack of suitable measurement sets for model evaluation highlights the need for further aerosol observational studies in Greece or similar areas, and a more complete routine monitoring effort as well, at areas affected by both natural (marine) and anthropogenic emissions. Measurement sites could be indicated by this (see for example Figs. 2, 4 and 7) and other relevant studies.

Acknowledgements. This research project (PENED) is co-financed by E.U.-European Social Fund (75\%) and the Greek Ministry of Development-GSRT (25\%). We want to thank the Greek Ministry of the Environment and the HPC-PASECO company for use of the emission data employed in the study.

Edited by: A. Nenes

\section{References}

Aleksandropoulou, V., and Lazaridis, M.: Spatial distribution of gaseous and particulate matter emissions in Greece, Water Air Soil Poll., 153, 1-4, 2004.

Alexander, B., Park, R. J., Jacob, D. J., Li, Q. B., Yantosca, R. M., Savarino, J., Lee, C. C. W., and Thiemens, M. H.: Sulfate formation in sea-salt aerosols: Constraints from oxygen isotopes, J. Geophys. Res., 110, D10307, doi:10.1029/2004JD005659, 2005.
Andreas, E. L.: Sea spray and the turbulent air-sea heat fluxes, J. Geophys. Res., 97, 11 429-11441, 1992.

Andreas, E.: A New Sea Spray Generation Function for Wind Speeds up to $32 \mathrm{~m} \mathrm{~s}^{-1}$, J. Phys. Oceanogr., 28(11), 2175-2184, 1998.

Anthes, R. A. and Warner, T. T.: Development of hydrodynamic models suitable for air pollution and other meteorological studies, Mon. Weather Rev., 106, 1045-1078, 1978.

Athanasopoulou, E., Bossioli, E., and Tombrou, M.: Modelling of aerosol in the Greater Athens Area, Greece, Int. J. Enviro. Pollut., 24, 230-246, 2005.

Bardouki, H., Liakakou, H., Economou, C., Sciare, J, Smolik, J., Ždímal, V., Eleftheriadis, K., Lazaridis, M., Dye, C., and Mihalopoulos, N.: Chemical composition of size-resolved atmospheric aerosols inthe eastern Mediterranean during summer and winter, Atmos. Environ., 37, 195-208, 2003.

Bassett, M. E. and Seinfeld, J.H.: Atmospheric equilibrium model of sulfate and nitrate aerosol, Atmos. Environ., 17, 2237-2252, 1983.

Bassett, M. E. and Seinfeld, J. H.: Atmospheric equilibrium model of sulfate and nitrate aerosol. II, Particle size analysis, Atmos. Environ., 18, 1163-1170, 1984.

Bessagnet, B., Hodzic, A., Vautard, R., Beekmann, M., Cheinet, S., Honore, C., Liousse, C., and Rouil, L.: Aerosol modeling with CHIMERE-preliminary evaluation at the continental scale, Atmos. Environ., 38, 2803-2817, 2004.

Binkowski, F. S. and Shankar, U.: The regional particulate matter model, 1: model description and preliminary results, J. Geophys. Res., 100, 26 191-26 209, 1995.

Blanchard, D. C.: The electrification of the atmosphere by particles from bubbles in the sea, Progr. Oceanogr., edited by: Sears, M., 73-202, Pergamon Press, New York, 1963.

Bortkovskii, R. S.: Air-Sea exchange of heat and moisture during storms, 194 pp., D. Reidel Publishing company, Dordrecht, 1987.

Bossioli, E., Tombrou, M., and Pilinis, C.: Adapting the Speciation of the VOCs Emission Inventory, in the Greater Athens Area, Water Air Soil Poll., Focus, 2(5-6), 141-153, 2002.

Byun, D. W., Pleim, J., Tang, R., and Bourgeois, A.: Meteorologychemistry interface processor (MCIP) for Models-3 Community Multiscale Air Quality (CMAQ) modeling system, in: Science Algorithms of the EPA Models-3 Community Multiscale Air Quality (CMAQ) Modeling System. Part II: Chapters 9-18, edited by: Byun, D. W., and Ching, J. K. S., EPA-600/R-99/030, National Exposure Research Laboratory, US Environmental Protection Agency, Research Triangle Park, NC, 12-1-12-86, 1999.

Capaldo, K. P., Pilinis, C., and Pandis, S. P.: A computationally efficient hybrid approach for dynamic gas/aerosol transfer in air quality models, Atmos. Environ., 34, 3617-3627, 2000.

Chang, J. S., Brost, R. A., Isaksen, I. S. A., Madronich, S., Middleton, P., Stockwell, W. R., and Walcek, C. J.: A three-dimensional Eulerian Acid Deposition Model: Physical concepts and formulation, J. Geophys. Res., 92, 14 681-14 700, 1987.

Clarke, A. D., Owens, S. R., and Zhou, J.: An ultrafine sea-salt flux from breaking waves: Implications for cloud condensation nuclei in the remote marine atmosphere, J. Geophys. Res., 111, D06202, doi:10.1029/2005JD006565, 2006.

Dandou A., Tombrou, M., Akylas, E., Soulakellis, N., and Bossioli, E.: Development and evaluation of an urban parameterization scheme in the Penn State/NCAR Mesoscale 
Model (MM5), J. Geophys. Res.-Atmos., 110, D06202, doi:10.1029/2005JD006565, 2005.

De Leeuw, G., Neele, F. P., Hill, M., Smith, M. H., and Vignati, E.: Production of sea spray aerosol in the surf zone, J. Geophys. Res., 105(D24), 29397-29410, 2000.

Eleftheriadis, K., Balis, D., Ziomas, I., Colbeck, I., and Manalis, N.: Atmospheric aerosol and gaseous species in Athens, Greece', Atmos. Environ., 32, 2183-2191, 1998a.

Eleftheriadis, K, Chung, M. C., and Colbeck, I.: Atmospheric aerosol formation over Athens, J. Aerosol Sci., 29, S25-S26, 1998b.

Eleftheriadis, K., Chung, M., Michaleas, S., and Colbeck, I.: Atmospheric aerosol evolution and transport over Athens, in: Proceedings of the Sixth Conference on Environmental Science and Technology, 30th August-2nd September 1999, edited by: Lekkas, Th., Samos, Greece, Vol. A. University of the Aegean, 137-144, 1999.

Eleftheriadis, K., Colbeck, I., Housiadas, C., Lazaridis, M., Mihalopoulos, N., Mitsakou, C., Smolík, J., and Ždímal, V.: Size distribution, composition and origin of the submicron aerosol in the marine boundary layer during the eastern Mediterranean "SUB-AERO" experiment, Atmos. Environ., 40(32), 62456260, 2006.

EMPA: Anteil des Strassenverkehrs an den $\mathrm{PM}_{10}$ und $\mathrm{PM}_{2.5}$ Imissionen, NFP41, Verkehr und Umwelt, Dübendorf, Switzerland, 2000.

Environ: User's guide to the comprehensive air quality model with extensions (CAMx), version 4.10s, report, ENVIRON Int. Corp., Novato, Calif., 2004.

Fairall, C. W., Davidson, K. L., and Schacher, G. E.: An analysis of the surface production of sea-salt aerosols, Tellus, 35B, 31-39, 1983.

Foltescu, V. L., Pryor, S. C., and Bennet, C.: Sea salt generation, dispersion and removal on the regional scale, Atmos. Environ., 39, 2123-2133, 2004.

Fountoukis, C. and Nenes, A.: ISORROPIA II: a computationally efficient thermodynamic equilibrium model for $\mathrm{K}^{+} \mathrm{Ca}^{2}+\mathrm{Mg}^{2}+\mathrm{NH}_{4}+\mathrm{Na}+\mathrm{SO}_{4}{ }^{2-} \mathrm{NO}_{3}{ }^{-} \mathrm{Cl}^{-} \mathrm{H}_{2} \mathrm{O}$ aerosols, Atmos. Chem. Phys., 7, 4639-4659, 2007,

http://www.atmos-chem-phys.net/7/4639/2007/.

Gathman, S. G.: A time-dependent oceanic aerosol profile model, NRL Report 8536, Naval Research Laboratory, Washington, DC, 35, 1982 .

Gery, M. W, Whitten, G. Z., Killus, J. P., and Dodge, M. C.: A photochemical kinetics mechanism for urban and regional scale computer modeling, J. Geophys. Res., 94, 12 925-12 956, 1989.

Gong S. L.: A parameterization of sea-salt aerosol source function for sub- and super-micron particles', Global Biogeochem. Cy., 17(4), pp.(8-)1-(8-)6, 2003.

Gong, S. L., Barrie, L. A., and Blanchet, J.-P: Modeling sea-salt aerosols in the atmosphere 1. Model development, J. Geophys. Res., 102(D3), 3805-3818, 1997.

Hien, P. D., Bac, V. T., and Thinh, N. T. H.: Investigation of sulfate and nitrate formation on mineral dust particles by receptor modeling, Atmos. Environ., 39, 7231-7239, 2005.

Hodzic, A., Bessagnet, B., and Vautard, R.: A model evaluation of coarse-mode nitrate heterogeneous formation on dust particles, Atmos. Environ., 40(22), 4158-4171, 2006.

Hoppel, W. A., Frick, G. M., and Fitzgerald, J. W.: Surface source function for sea-salt aerosol and aerosol dry deposition to the ocean surface, J. Geophys. Res., 107, 1-17, 2002.

Iida, N., Toba, Y., and Chaen, M.: A new expression for the production rate of sea water droplets on the sea surface, J. Oceanography, 48(4), 439-460, 1992.

Kassomenos, P., Flocas, H. A., Lykoudis, S., and Petrakis, M.: Analysis of mesoscale patterns in relation to synoptic conditions over an urban Mediterranean basin. Theor. Appl. Climatol., 59, 215-229, 1998.

Koo, B., Gaydos, T. M., and Pandis, S. N.: Evaluation of the equilibrium, hybrid, and dynamic aerosol modeling approaches, Aerosol Sci. Tech., 37, 53-64, 2003.

Lazaridis, M., Eleftheriadis, K., Smolik, J., Colbeck, I., Kallos, G., Drossinos, Y., Zdimal, V., Vecera, Z., Mihalopoulos, N., Mikuska, P., Bryant, C., Housiadas, C., Spyridaki, A., Astitha, M., and Havranek, V.: Dynamics of fine particles and photooxidants in the Eastern Mediterranean (SUB-AERO), Atmos. Environ., 40, 6214-6228, 2006.

Lewis, E. R. and Schwartz, S. E.: Sea Salt Aerosol Production: Mechanisms, Methods, Measurements, and Models: A Critical Review, American Geophysical Union, Washington, DC, 2004.

Lewis, E. R. and Schwartz, S. E.: Comment on "size distribution of sea-salt emissions as a function of relative humidity", Atmos. Environ., 40, 588-590, 2006.

Ling, S. C., Kao, T. W., and Saad, A. I.: Microdroplets and transport of moisture from ocean, J. Eng. Mech. Div.-Asce, 106, 13271339, 1980.

Lurmann, F. W., Wexler, A. S., Pandis, S. N., Musarra, S., Kumar, N., and Seinfeld, J. H.: Modeling urban and regional aerosols-II. Application to California's south coast air basin, Atmos. Environ., 31, 2695-2715, 1997.

Ma, X., Salzen, K., and Li, J.: Modelling sea salt aerosol and its direct and indirect effects on climate, Atmos. Chem. Phys., 8, 1311-1327, 2008, http://www.atmos-chem-phys.net/8/1311/2008/.

Martensson, E. M., Nilsson, E. D., De Leeuw, G., Cohen, L. H. and Hansson, H.-C.: Laboratory simulations and parameterization of the primary marine aerosol production, J. Geophys. Res., 108(D9), 4297, doi:10.1029/2002JD002263, 2003.

Mebust, M. R., Eder, B. K., Binkowski, F. S., and Roselle, S. J.: Models-3 Community Multiscale Air Quality (CMAQ) model aerosol component. 2. Model evaluation, J. Geophys. Res., 108(D6), 4184, doi:10.1029/2001JD001410, 2003.

Melas, D., Ziomas, I., Klemm, O., and Zerefos, C. S.: Anatomy of the sea-breeze circulation in Athens area under weak largescale ambient winds, Atmos. Environ., 32(12), 2223-2237, 1998.

Meng, Z. and Seinfeld, J. H.: Timescales to achieve atmospheric gas-aerosol equilibrium for volatile species, Atmos. Environ., 30, 2889-2900, 1996.

Monahan, E. C.: Coastal Aerosol Workshop Proceedings, edited by: Goroch, A. K. and Geernaert, G. L., Rep. NRL/MR/754295-7219, 138 pp., Nav. Res. Lab., Monterey, Calif., 1995.

Monahan, E. C., Spiel, D. E., and Davidson, K. L.: A model of marine aerosol generation via whitecaps and wave disruption, in: Oceanic Whitecaps, edited by: Monahan, E. and Niocaill, G. M., 167-174, D. Reidel, Norwell, Mass, 1986.

Nenes, A., Pilinis, C., and Pandis, S. N.: ISORROPIA: a new thermodynamic equilibrium model for multiphase multicomponent marine aerosols, Aquat. Geochem., 4, 123-152, 1998. 
Nolte, C. N., Bhave, P. V., Arnold, J. R., Dennis, R. L., Zhang, K. M., and Wexler, A. S.: Modeling urban and regional aerosolsApplication of the CMAQ-UCD Aerosol Model to Tampa, a coastal urban site, Atmos. Environ., 42, 3179-3191, 2008.

O'Brien, J.: A Note on the Vertical Structure of the Eddy Exchange Coefficient in the Planetary Boundary Layer, J. Atmos. Sci., 27(8), 1213-1215, 1970.

O’Dowd, C., Smith, M. H., Ian, C. E., and Jason, L. A.: Marine Aerosol, Sea-Salt, And The Marine Sulphur Cycle: A Short Review, Atmos. Environ., 31(1), 73-80, 1997.

Pierce, J. R. and Adams, P. J.: Global evaluation of CCN formation by direct emission of sea salt and growth of ultrafine sea salt, J. Geophys. Res., 111, D06203, doi:10.1029/2005JD006186, 2006.

Pryor, S. C., Barthelmie, R. J., Schoof, J. T., Binkowski, F. S., Monache, L. Delle, and Stull, R.: Modeling the impact of seaspray on particle concentrations in a coastal city, Sci. Tot. Environ., 391, 132-142, 2008.

Salvador, P., Begoña, A., Xavier, Q., Andrés A., and Miguel, C.: Characterisation of local and external contributions of atmospheric particulate matter at a background coastal site, Atmos. Environ., 41, 1-17, 2007.

Saxena, P., Seigneur, C., Hudischewskyj, A. B., and Seinfeld, J. H.: A comparative study of equilibrium approaches to the chemical characterizations of secondary aerosols, Atmos. Environ., 20, 1471-1484, 1986.

Scheff, P. A. and Valiozis, C.: Characterization and source identification of respirable particulate matter in Athens, Greece, Atmos. Environ., 24(A1), 203-211, 1990.

Seinfeld, J. H. and Pandis, S. P.: Atmospheric chemistry and physics - from air pollution to climate change, John Wiley \& Sons, Inc., 1998.

Shankar, U., Bhave, P. V., Vukovich, J. M., and Roselle, S. J.: Implementation and initial applications of sea salt aerosol emissions and chemistry algorithms in the CMAQ v4.5 -AERO4 module,Models-3 Users' Conference, P.6, Chapel Hill, September 2005.

Siskos, P. A., Bakeas, E. B., Lioli, I., Smirnioudi, V. N., and Koutrakis, P.: Chemical characterization of PM2.5 aerosols in Athens-Greece, Environ. Technol., 22, 687-695, 2001.

Smith, M. H. and Harrison, N. M.: The Sea Spray Generation Function, J. Atmos. Sci., 29, S189-S190, 1998.

Smith, M. H., Park, P. M., and Consterdine, I. E.: Marine aerosol concentrations and estimated fluxes over the sea, Q. J. Roy. Meteorol. Soc., 119, 809-824, 1993.

Smolik, J., Ždímal, V., Schwarz, J., Lazaridis, M., Havranek, V., Eleftheriadis, K., Mihalopoulos, N., Bryant, C., and Colbeck, I.: Size resolved mass concentration and elemental composition of atmospheric aerosols over the Eastern Mediterranean area, Atmos. Chem. Phys., 3, 2207-2216, 2003,

http://www.atmos-chem-phys.net/3/2207/2003/.

Sotiropoulou, R. E. P., Tagaris, E., and Pilinis, C.: An estimation of the spatial distribution of agricultural ammonia emissions in the Greater Athens Area, Sci. Tot. Environ., 318, 159-169, 2003
Spyridaki, A., Lazaridis, M., Eleftheriadis, K., Smolik, J., Mihalopoulos, N., and Aleksandropoulou, V.: Modelling and evaluation of size-resolved aerosol characteristics in the Eastern Mediterranean during the SUB-AERO project, Atmos. Environ., 40, 6261-6275, 2006.

Strader, R., Gurciullo, C., Pandis, S. N., Kumar, N., and Lurmann, F. W.: Development of gas-phase chemistry, secondary organic aerosol, and aqueous-phase chemistry modules for PM modelling, Final report for CRC Project A21-1 prepared for the Coordinating Research Council, Atlanta, GA by Sonoma Technology, Inc. Petaluma, CA, STI-97510-1822-FR, October, 1998.

Torfs, K. and Grieken, van R.: Chemical relations between atmospheric aerosols, deposition and stone decay layers on historic buildings at the Mediterranean coast, Atmos. Environ., 31, 21792192, 1997.

Tsitouridou, R., Voutsa, D., and Kouimtzis., T.: Ionic composition of PM10 in the area of Thessaloniki, Greece, Chemosphere, 52, 883-891, 2003.

Vignati, E., de Leeuw, G., and Berkowicz., R.: Modeling coastal aerosol transport and effects of surf-produced aerosols on processes in the marine atmospheric boundary layer, J. Geophys. Res., 106(D17), 20 225-20 238, 2001.

Wall, S. M., John, W., and Ondo, J. L.: Measurement of aerosol size distributions for nitrate and major ionic species, Atmos. Environ., 22, 1649-1656, 1988.

Witek, M. L., Flatau, P. J., Quinn, P. K., and Westphal, D. L.: Global sea-salt modeling: Results and validation against multicampaign shipboard measurements, J. Geophys. Res., 112, D08115, doi:10.1029/2006JD007779, 2007.

Woodcock, A. H., Blanchard, D. C., and Rooth, C. G. H.: Saltinduced convection and clouds, J. Atmos. Sci., 20, 159-169, 1963.

Woolf, D. K., Monahan, E. C., and Spiel, D. E.: Quantification of the marine aerosol produced by whitecaps, in Seventh Congress on Ocean-Atmosphere Interaction, 182-185, Am. Meteorol. Soc., Anaheim, CA, 1988.

Wu, J.: Bubble flux and marine aerosol spectra under various wind velocities, J. Geophys. Res., 97(C2), 2327-2333, 1992.

$\mathrm{Wu}, \mathrm{J}$.: Production of spume drops by the wind tearing of wave crests: the search for quantification, J. Geophys. Res., 98 (C10), 18 221-18 227, 1993.

Zhang, K. M., Knipping, M. E., Wexler, A. S., Bhave, P. V, and Tonnesen, S. G.: Size distribution of sea-salt emissions as a functions of relative humidity, Atmos. Environ., 39, 3373-3379, 2005a.

Zhang, K. M., Knipping, M. E., Wexler, A. S., Bhave, P. V., and Tonnesen, S. G.: Reply to comment on "Size distribution of seasalt emissions as a function of relative humidity", Atmos. Environ., 40(3), 591-592, 2005b.

Zhang, Y., Seigneur, C., Seinfeld, J. H., Jacobson, M., Clegg, S. L., and Binkowski, F. S.: A comparative review of inorganic aerosol thermodynamic equilibrium modules: similarities, differences, and their likely causes, Atmos. Environ., 34, 117-137, 2000.

Ziomas, I., Melas, D., Zerefos, C. S., Bais, A. F., and Paliatsos, A. G.: Forecasting peak pollutant levels from meteorological variables, Atmos. Environ., 29, 3703-3711, 1995. 